Reexamination of the Subsurface Fault Structure in the Vicinity of the 1989 Moment-Magnitude-6.9 Loma Prieta Earthquake, Central California, Using Steep-Reflection, Earthquake, and Magnetic Data

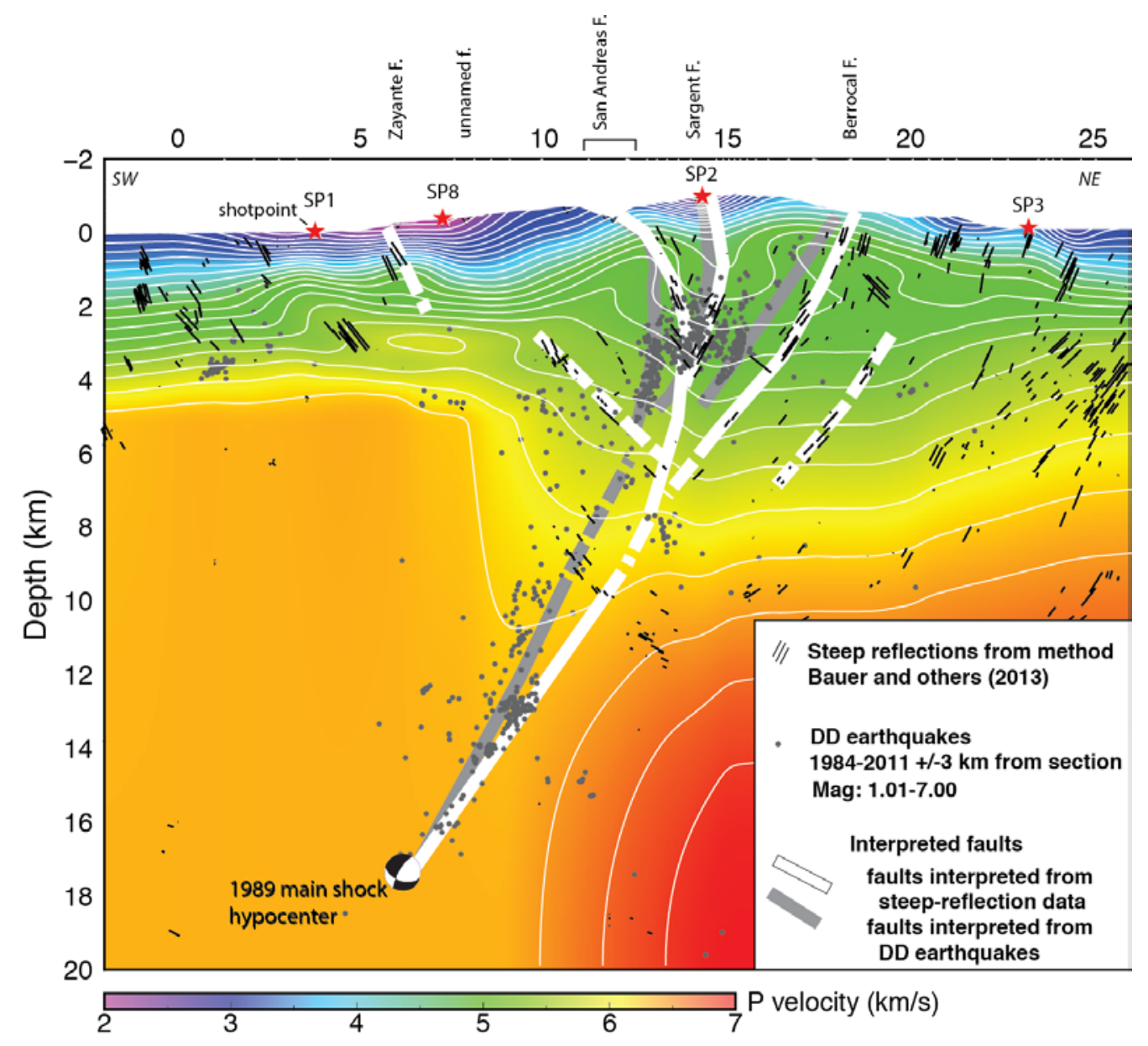

Open-File Report 2018-1093

U.S. Department of the Interior U.S. Geological Survey 
Cover. Illustration showing faults interpreted from steep-reflection data compared to faults interpreted from aftershocks relocated by wave-form cross correlation and double-difference techniques for the 1989 Loma Prieta, California, earthquake. These two fault geometries are similar and support a continuity between faults interpreted in the upper crust $(<10$ kilometers, $\mathrm{km})$ and the mainshock rupture in the middle crust $(>10 \mathrm{~km}) . \mathrm{km} / \mathrm{s}$, kilometers per second; F., Fault; SW, southwest; NE, northeast; DD, relocated earthquakes from double-difference and wave-form cross-correlation methods; Mag., magnitude; P, compressional wave. 


\title{
Reexamination of the Subsurface Fault Structure in the Vicinity of the 1989 Moment-Magnitude-6.9 Loma Prieta Earthquake, Central California, Using Steep-Reflection, Earthquake, and Magnetic Data
}

\author{
By Edward Zhang, Gary S. Fuis, Rufus D. Catchings, Daniel S. Scheirer, Mark Goldman, and Klaus Bauer
}

Open-File Report 2018-1093

U.S. Department of the Interior

U.S. Geological Survey 


\section{U.S. Department of the Interior \\ RYAN K. ZINKE, Secretary}

U.S. Geological Survey
James F. Reilly II, Director

U.S. Geological Survey, Reston, Virginia: 2018

For more information on the USGS—-the Federal source for science about the Earth, its natural and living resources, natural hazards, and the environment-visit https://www.usgs.gov/ or call 1-888-ASK-USGS (1-888-275-8747).

For an overview of USGS information products, including maps, imagery, and publications, visit https://store.usgs.gov/.

Any use of trade, firm, or product names is for descriptive purposes only and does not imply endorsement by the U.S. Government.

Although this information product, for the most part, is in the public domain, it also may contain copyrighted materials as noted in the text. Permission to reproduce copyrighted items must be secured from the copyright owner.

Suggested citation:

Zhang, E., Fuis, G.S., Catchings, R.D., Scheirer, D.S., Goldman, M., and Bauer, K., 2018, Reexamination of the subsurface fault structure in the vicinity of the 1989 moment-magnitude-6.9 Loma Prieta earthquake, central California, using steep-reflection, earthquake, and magnetic data: U.S. Geological Survey Open-File Report 20181093, 35 p., https://doi.org/10.3133/ofr20181093.

ISSN 2331-1258 (online) 


\section{Contents}

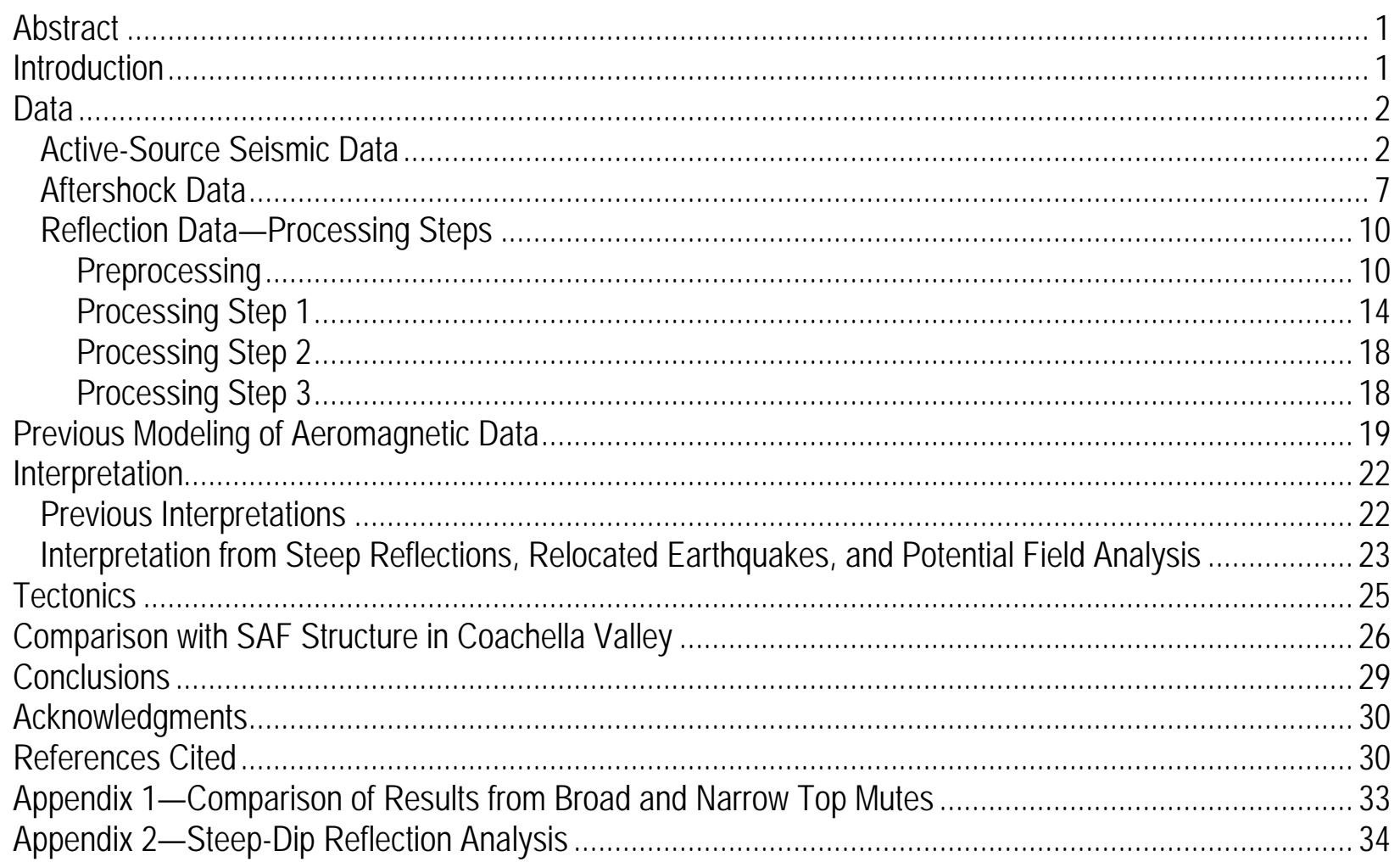

\section{Figures}

1. Map showing the locations of active faults, epicenter of the 1989 moment-magnitude 6.9 Loma Prieta earthquake, and seismic and potential-field profiles, San Francisco Bay region,

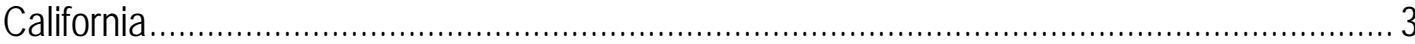

2. Cross sections showing velocity models along the Loma Prieta profile .................................. 6

3. Cross sections showing earthquakes plotted on a velocity model along the Loma Prieta profile

4. Graphs showing Fast Fourier transforms (FFTs) of data collected along the Loma Prieta profile ...................................................................................................... 11

5. Plot showing unprocessed seismic data from shotpoint 8 of the Loma Prieta profile............. 12

6. Plot showing top and bottom mutes applied to the shot gather of figure 5, to remove direct and refracted $\mathrm{P}$ waves, $\mathrm{S}$ waves, and surface waves

7. Plot showing bandpass filter $5-10-20-30 ~ H z$ and $60-\mathrm{Hz}$ notch filter applied to the shot gather of figure 6

8. Plot showing automatic gain control, with an operator length of 500 milliseconds, applied to

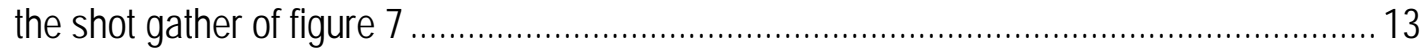

9. $\quad$ Plot showing time-variant spectral whitening applied to the shot gather of figure $8 \ldots \ldots \ldots \ldots \ldots . . .14$

10. Plot showing all preprocessing applied to the shot gather of figure 5, without the top and bottom mutes 
11. Illustrations showing reverse-moveout reflections picked on the preprocessed shot gather from shotpoint 8 of the Loma Prieta profile (see fig. 1 for location) and migration of these reflections in the depth domain

12. Illustrations showing reverse-moveout reflections picked on the preprocessed shot gather from shotpoint 3 of the Loma Prieta profile (see fig. 1 for location) and migration of these reflections in the depth domain

13. Illustration showing final output of migrated reverse-moveout reflections for all 4 shotpoints of the Loma Prieta profile.

14. Map of the Loma Prieta region, California, from Jachens and Griscom (2004; their fig. 11), showing distribution of aftershocks of the 1989 Loma Prieta earthquake

15. Illustration from Jachens and Griscom (2004; their fig. 13) showing magnetic data and modeling along profile $\mathrm{E}-\mathrm{E}$.

16. Illustration from Jachens and Griscom (2004; their fig. 15) showing magnetic data and modeling along profile $\mathrm{S}^{-\mathrm{S}^{\prime}}$

17. Illustrations showing previous rupture interpretations for the 1989 Loma Prieta, California, earthquake by Dietz and Ellsworth (1990) and Bürgmann and others (2004).

18. Illustration showing fault interpretations for the 1989 Loma Prieta, California, earthquake from seismic-reflection data of this study

19. Illustration showing fault interpretations for the 1989 Loma Prieta, California, earthquake from relocated aftershocks from this study.

20. Illustration showing nonplanar San Andreas Fault and flower-like structure imaged in the Coachella Valley of southern California by Fuis and others (2017)...

21. Comparison of fault structure geometry in the epicentral area of the 1989 Loma Prieta, California, earthquake interpreted from this study with that interpreted for line 4 of the Salton Seismic Imaging Project

22. Comparison of reflections obtained in the epicentral area of the 1989 Loma Prieta, California, earthquake using a broad top mute with reflections from using a narrow top mute.

23.

Diagrams showing the prestack migration technique of Bauer and others (2013). 


\section{Conversion Factors}

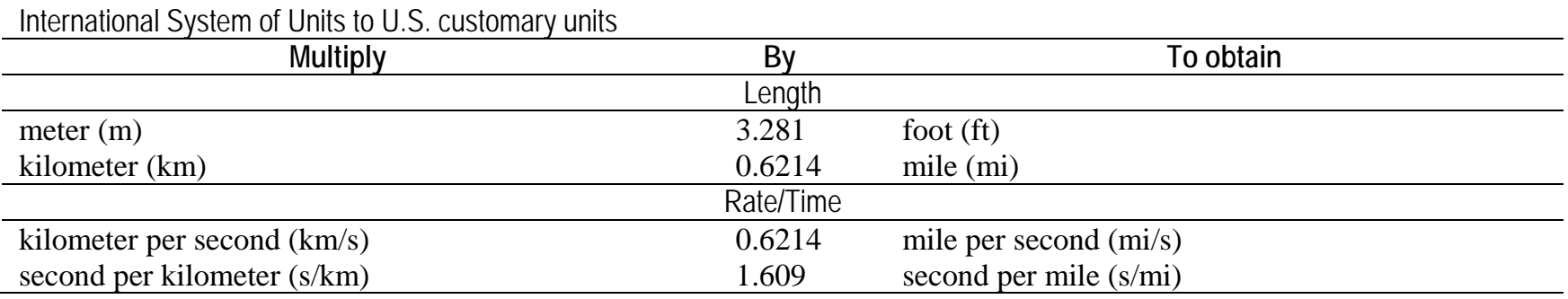

\section{Abbreviations and Acronyms}

AGC automatic gain control

FFT fast Fourier transform

$\mathrm{Hz} \quad$ hertz

ms millisecond

NE northeast

NW northwest

SAF San Andreas Fault

SE southeast

SP shotpoint

SSIP Salton Seismic Imaging Project

SW southwest

TV time variant

USGS U.S. Geological Survey 


\title{
Reexamination of the Subsurface Fault Structure in the Vicinity of the 1989 Moment-Magnitude-6.9 Loma Prieta Earthquake, Central California, Using Steep-Reflection, Earthquake, and Magnetic Data
}

\author{
By Edward Zhang, ${ }^{1,2}$ Gary S. Fuis, ${ }^{1}$ Rufus D. Catchings, ${ }^{1}$ Daniel S. Scheirer,${ }^{1}$ Mark Goldman, ${ }^{1}$ and Klaus Bauer ${ }^{3}$
}

\begin{abstract}
We reexamine the geometry of the causative fault structure of the 1989 moment-magnitude-6.9 Loma Prieta earthquake in central California, using seismic-reflection, earthquake-hypocenter, and magnetic data. Our study is prompted by recent interpretations of a two-part dip of the San Andreas Fault (SAF) accompanied by a flower-like structure in the Coachella Valley, in southern California. Initially, the prevailing interpretation of fault geometry in the vicinity of the Loma Prieta earthquake was that the mainshock did not rupture the SAF, but rather a secondary fault within the SAF system, because network locations of aftershocks defined neither a vertical plane nor a fault plane that projected to the surface trace of the SAF. Subsequent waveform cross-correlation and double-difference relocations of Loma Prieta aftershocks appear to have clarified the fault geometry somewhat, with steeply dipping faults in the upper crust possibly connecting to the more moderately southwest-dipping mainshock rupture in the middle crust. Examination of steep-reflection data, extracted from a 1991 seismic-refraction profile through the Loma Prieta area, reveals three robust fault-like features that agree approximately in geometry with the clusters of upper-crustal relocated aftershocks. The subsurface geometry of the San Andreas, Sargent, and Berrocal Faults can be mapped using these features and the aftershock clusters. The San Andreas and Sargent Faults appear to dip northeastward in the uppermost crust and change dip continuously toward the southwest with depth. Previous models of gravity and magnetic data on profiles through the aftershock region also define a steeply dipping SAF, with an initial northeastward dip in the uppermost crust that changes with depth. At a depth 6 to $9 \mathrm{~km}$, uppercrustal faults appear to project into the moderately southwest-dipping, planar mainshock rupture. The change to a planar dipping rupture at 6-9 km is similar to fault geometry seen in the Coachella Valley.
\end{abstract}

\section{Introduction}

The U.S. Geological Survey (USGS) collected a number of active-source seismic datasets in the San Francisco Bay region following the 1989 moment-magnitude-6.9 $\left(M_{\mathrm{w}}\right)$ Loma Prieta earthquake (Catchings and others, 2004). One of these datasets is a profile extending approximately $25 \mathrm{~km}$

\footnotetext{
${ }^{1}$ U.S. Geological Survey.

${ }^{2}$ Oregon State University.

${ }^{3}$ Deutsches GeoForschungsZentrum (GFZ), Telegrafenberg, D-14473 Potsdam, Germany.
} 
northeastward from Aptos, California, to the Calero Reservoir in the Santa Clara Valley, through the vicinity of the Loma Prieta epicenter (fig. 1). This profile was recorded in 1991, and we will refer to it as the Loma Prieta profile.

Analysis of the Loma Prieta earthquake and aftershock sequence by numerous authors (for example, Dietz and Ellsworth, 1990, 1997; Beroza, 1996; Eberhart-Phillips and Michael, 1998, 2004) revealed a main rupture plane that dips $65-70^{\circ}$ southwest (SW) from a point located approximately 7 kilometers $(\mathrm{km})$ deep and 1-2 km SW of the surface trace of the San Andreas Fault (SAF). The preferred interpretation was that the rupture plane was not the main branch of the SAF, given its SW dip and the fact that it did not project to the surface trace of the SAF, but a secondary fault within the SAF system (see summaries by Spudich, 1996; Reasenberg, 1997; and Wells, 2004).

Recent analyses of data on profiles crossing the SAF in the Coachella Valley of southern California indicate a geometry similar to (but reversed from) that seen at Loma Prieta (Fuis and others, 2017). In the Coachella Valley at depths below 6-9 km, the SAF dips moderately northeast (NE) and does not project to the surface trace. The upper part of the SAF dips steeply NE. These analyses included mapping of steeply dipping reflections using the processing method of Bauer and others (2013), study of relocated hypocenters, and modeling of potential-field data. The data also reveal a flower-like structure, mainly in the hanging wall of the SAF, above a depth of about $10 \mathrm{~km}$. Thus, the SAF in Coachella Valley appears both nonvertical and nonplanar.

This new image of the SAF in the Coachella Valley motivated our reexamination of fault geometry in the vicinity of the Loma Prieta earthquake using methods similar to those used for the Coachella Valley. The main question to resolve is: Was the 1989 rupture on the main transform plate boundary fault, namely the SAF, or on a secondary fault? The acquisition geometry used to acquire the 1991 dataset was not ideal for steep-dip migration because the station spacing was about twice the optimal value (see below and Bauer and others, 2013). Nevertheless, it seemed worthwhile to attempt an analysis of the Loma Prieta profile for steep reflections.

\section{Data}

Data analyzed in this study include active-source seismic data from the 1991 Loma Prieta profile, collected by Catchings and others (2004), and aftershocks of the Loma Prieta earthquake that were relocated using wave-form cross correlation and double-difference techniques by Schaff and Waldhauser (2005) and Waldhauser and Schaff (2008a, 2008b). We also examined previous potentialfield modeling on profiles near to the Loma Prieta profile.

\section{Active-Source Seismic Data}

The 1991 Loma Prieta seismic profile extended approximately $25 \mathrm{~km}$ across the epicentral area of the Loma Prieta earthquake, from Aptos, California, northeastward to Calero Reservoir in the Santa Clara Valley (fig. 1; Catchings and others, 2004). The active-source seismic data were obtained from four inline shots, or explosions, spaced approximately $5 \mathrm{~km}$ apart, and 172 receivers deployed along the profile. The average receiver spacing was approximately 150 meters (m). 


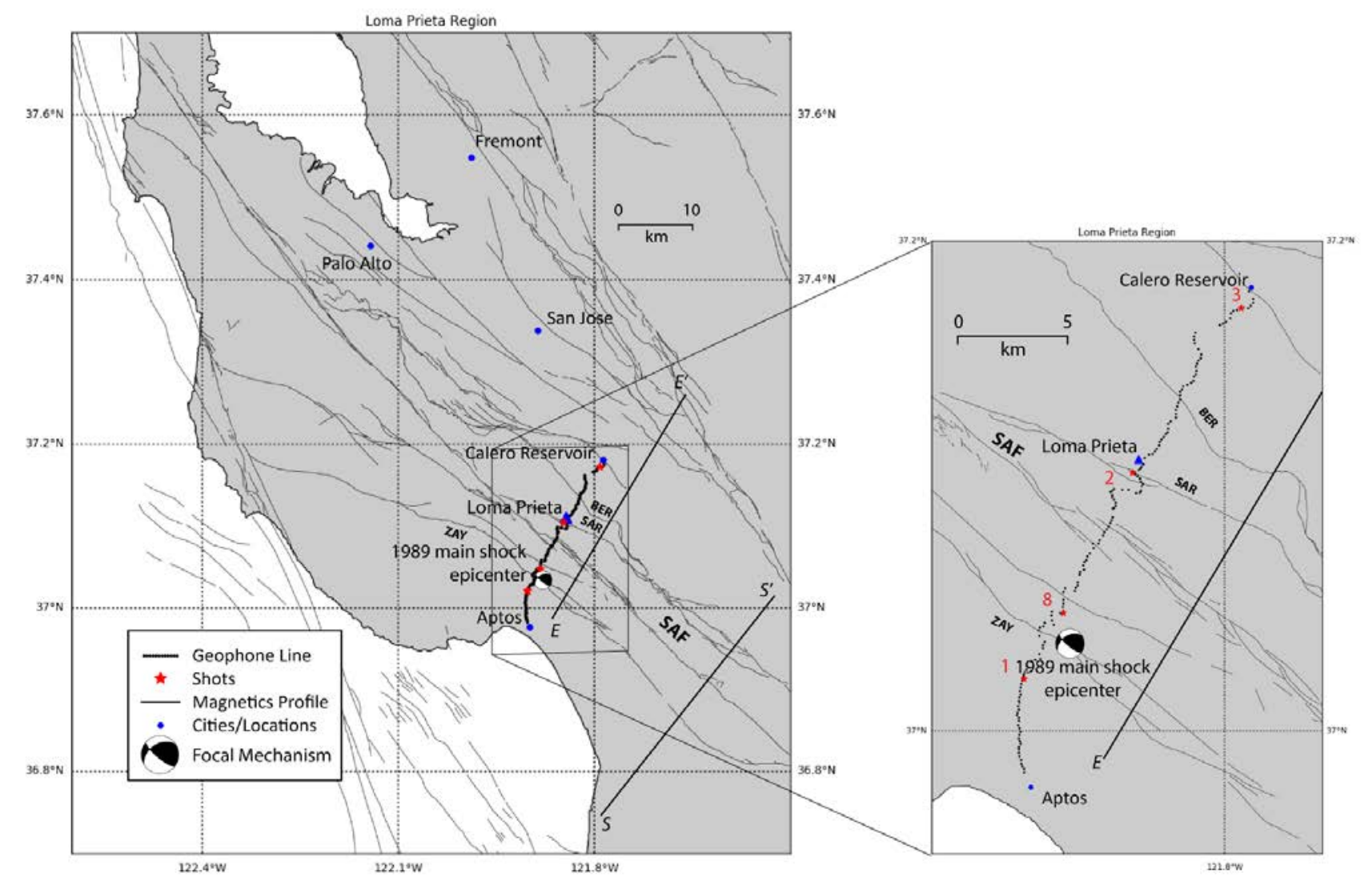

Figure 1. Map showing the locations of active faults, epicenter of the 1989 moment-magnitude 6.9 Loma Prieta earthquake, and seismic and potential-field profiles, San Francisco Bay region, California. Faults are from Jennings and Bryant (2010). The seismic profile, referred to as the Loma Prieta profile (Catchings and others, 2004), is represented by small triangles (receivers) and red stars (shotpoints). Potential-field profiles (Jachens and Griscom, 2004) are straight lines E-E' and S-S'. BER, Berrocal Fault; SAF, San Andreas Fault; SAR, Sargent Fault; ZAY, Zayante Fault.

A compressional-wave (P-wave) seismic-velocity model was generated from inversion of first arrivals using the method of Hole (1992) (Catchings and others, 2004, their fig. 3). This model (fig. 2A) is characterized by a vertically oriented, $\sim 2-\mathrm{km}$-wide low-velocity zone extending to a depth of about 3 $\mathrm{km}$ beneath Loma Prieta, which is the high point on the profile. This low-velocity zone is centered about $2 \mathrm{~km}$ north of the surface trace of the SAF, approximately beneath the trace of the Sargent Fault. Rocks southwest of this zone are higher in velocity than rocks to the northeast. The initial model had dimensions of -2.0 to $26 \mathrm{~km}$ from SW to NE and -2.0 to $5 \mathrm{~km}$ in depth. Using as a guide the results of the Cross Bay profile of Catchings and others (2004, their fig. 5), located approximately $50 \mathrm{~km}$ north of the Loma Prieta profile, the initial model (fig. 2A) was extended to a depth of $20 \mathrm{~km}$, to migrate any deep reflections found in our study. A velocity extrapolation was applied from about 4 to $20 \mathrm{~km}$ depth, with velocities increasing to 6.3 kilometers per second $(\mathrm{km} / \mathrm{s})$ at 20-km depth southwest of the SAF and $7.0 \mathrm{~km} / \mathrm{s}$ at $20-\mathrm{km}$ depth northeast of the fault (fig. 2B). This model is consistent with the tomographic velocity results of Eberhart-Phillips and Michael $(1998,2004)$ above about 10-km depth but differs somewhat at greater depth. In our study, we detect no clear reflections below about 10-km depth, making velocity-model differences below this depth of less concern. 
The dominant seismic frequencies from the explosions are 10-20 Hz (see below), and dominant velocities in the uppermost $5 \mathrm{~km}$ are $4-5 \mathrm{~km} / \mathrm{s}$ (fig. $2 A$ ). The optimum receiver spacing should average $\sim 80 \mathrm{~m}$, in order to sample 4 data points per wavelength. Given an average receiver spacing of $\sim 150 \mathrm{~m}$ for the Loma Prieta profile, the geometry of this profile is not ideal for application of the method of Bauer and others (2013). 


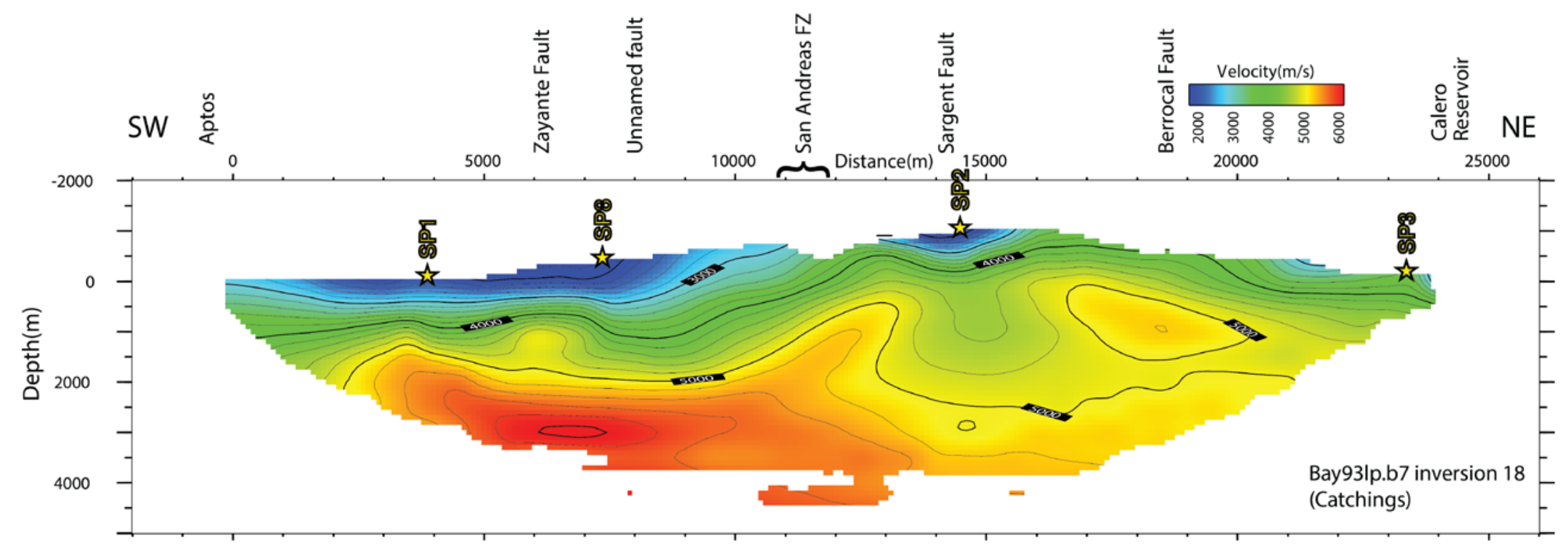

No Vertical Exaggeration 


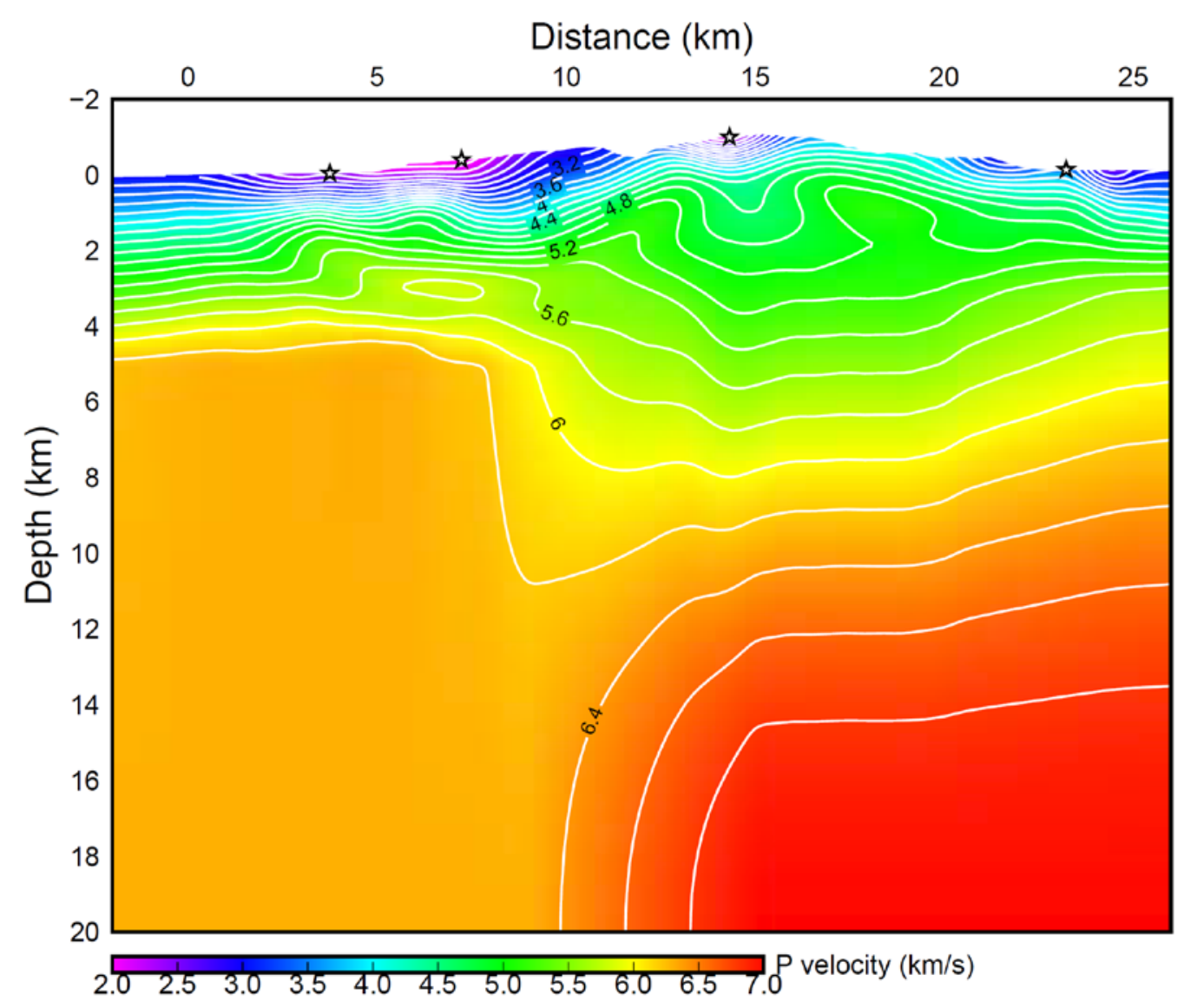

Figure 2. Cross sections showing velocity models along the Loma Prieta profile (see fig. 1 for location). A, Velocity model from Catchings and others (2004, their fig.3; FZ, Fault Zone; $\mathrm{m}$, meter; m/s, meters per second). $B$, Velocity model (A) extrapolated from a depth of 4 to 20 kilometers $(\mathrm{km})$ as described in text of this report (red stars, shotpoints; contour interval, 0.2 kilometers per second, km/s; $P$, compressional wave). 


\section{Aftershock Data}

Aftershock locations in the Loma Prieta epicentral area were discussed in Dietz and Ellsworth (1990, 1997). These aftershocks were subsequently relocated using the double-difference and waveform cross-correlation methods of Schaff and Waldhauser (2005) and Waldhauser and Schaff (2008a, 2008b). Velocity models used for relocation are also described in the latter reference. The aftershock hypocenters that we analyzed are from version 201112.1 of the Double-Difference Earthquake Catalog for Northern California (NCAeqDD) catalog series, which spans 1984-2011 (Waldhauser and Schaff, 2008a). Along the Loma Prieta profile, these relocated aftershocks form two main clusters, a tabular zone rising from a depth of $18 \mathrm{~km}$ to a depth of $9 \mathrm{~km}$ and a broader, complex cluster above a depth of 5 km (fig. 3A). The deeper cluster has been interpreted to define the main rupture plane, which dips 6570 SW (Dietz and Ellsworth, 1990, 1997; Beroza, 1996; Eberhart-Phillips and Michael, 1998, 2004). The hypocenter relocations of the shallower events define tabular to curved subclusters that suggest connections among the main rupture and the surface traces of the SAF, Sargent Fault, and Berrocal Fault (fig. 3B), especially when examined in conjunction with steep-reflection and potential-field data (see below). 


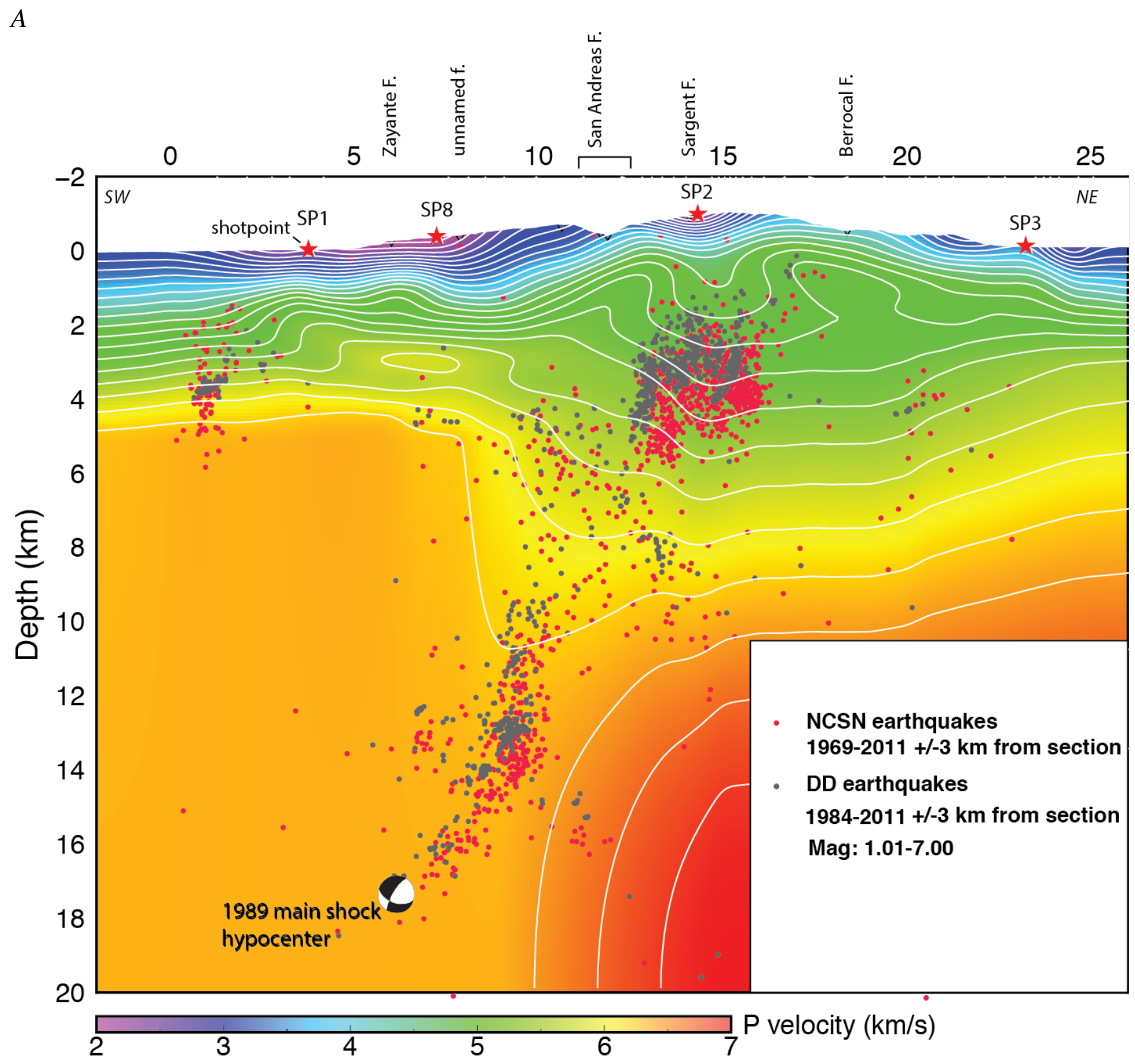




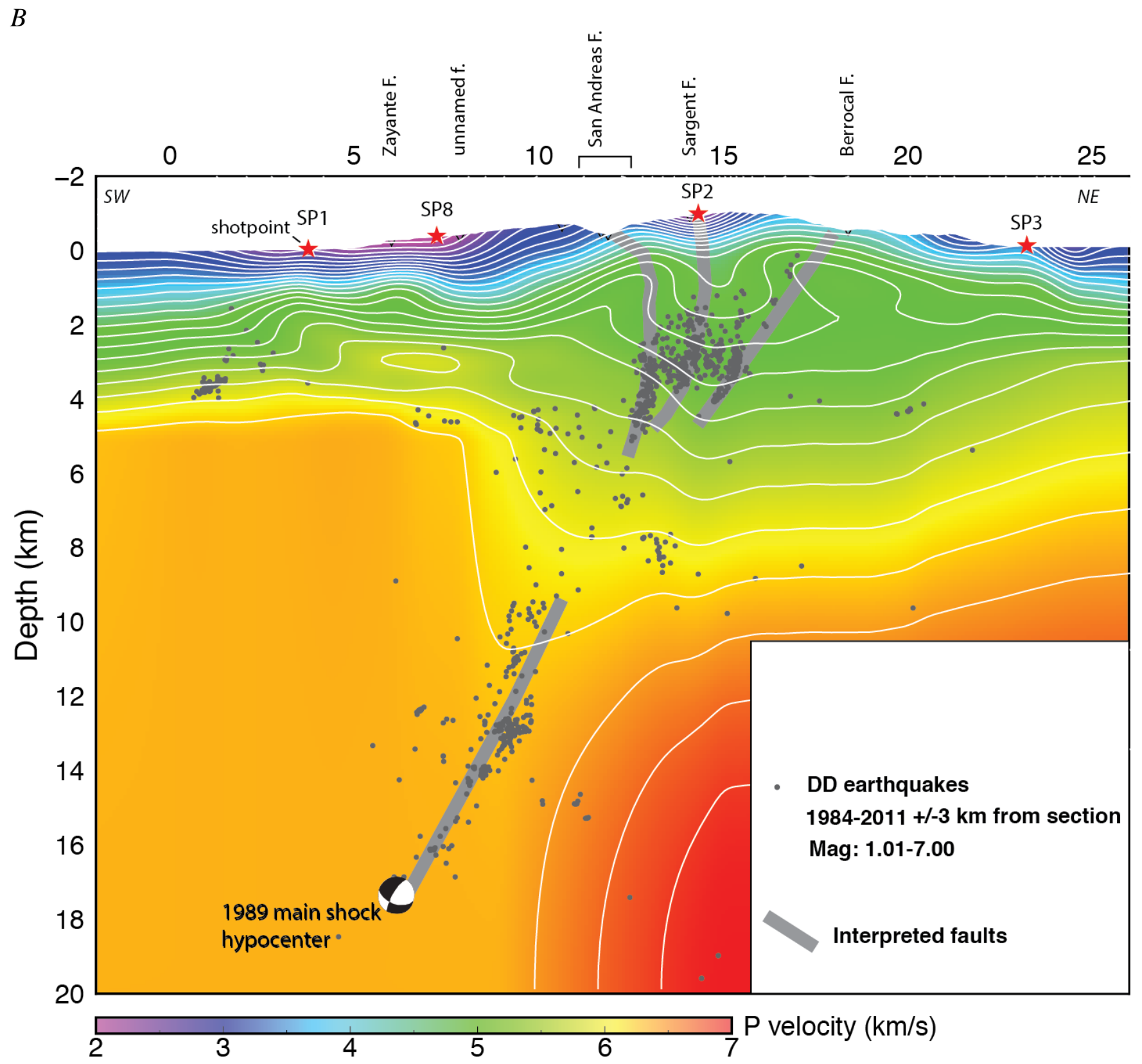

Figure 3. Cross sections showing earthquakes plotted on a velocity model along the Loma Prieta profile (see fig. 1 for location). A, All earthquakes within 3 kilometers $(\mathrm{km})$ of the Loma Prieta profile plotted on the velocity model of figure $2 B$. Contour interval 0.2 kilometers per second $(\mathrm{km} / \mathrm{s}$ ) (see fig. $2 B$ ). $B$, Same as $(A)$ with faults interpreted in this study in gray. The curvature of the San Andreas Fault (SAF) in the upper $2 \mathrm{~km}$ is inferred from (1) the sharp lateral gradient in the velocity model (see velocity contours in this figure; see also fig. 2A) and (2) analogy with the uppermost interpreted SAF in the models of steep-reflection data (see below) and magnetic data along a subparallel profile $5 \mathrm{~km}$ southeast of the Loma Prieta profile (Jachens and Griscom, 2004, profile E-E'). F., Fault; SW, southwest; NE, northeast; NCSN, Northern California Seismic Network catalog earthquakes from NCEDC (2014); DD, relocated earthquakes from wave-form cross correlation and double-difference techniques by Schaff and Waldhauser (2005) and Waldhauser and Schaff (2008a).; Mag., magnitude; P, compressional wave. 


\section{Reflection Data—Processing Steps}

A three-step procedure developed by Bauer and others (2013) was used to select and migrate steep reflections from each shot gather of the Loma Prieta profile. Data were preprocessed and then processed in three steps.

\section{Preprocessing}

The procedure of Bauer and others (2013) requires the data to be preprocessed to remove unwanted phases and coherent noise. Traces in the shot gathers that were visibly dead or noisy were first removed. The preprocessing steps that produced the most significant positive results in the final output of the reflection model were the top mute, the bandpass filter, time-variant (TV) spectral whitening, and automatic gain control (AGC). A top mute was applied to the data to remove large-amplitude direct and refracted waves following the first arrivals. A broad top mute was used that eliminates the first three to four peaks following the first-arrivals. We also used a narrow top mute that eliminates only the first two peaks. Results from these two top mutes are compared in appendix 1. A bandpass filter of 5-10-20-30 hertz (Hz) was applied to the top-muted data to center filtering on dominant frequencies of our seismic signals. A fast Fourier transform (FFT) applied to the raw data (fig. 4) shows higher amplitudes in the region of the selected bandpass. TV spectral whitening was applied to the same $5-10-20-30 \mathrm{~Hz}$ frequency window to equalize the spectrum without significantly increasing noise. An AGC with an operator length of 500 milliseconds (ms) was applied to normalize the traces, improving signal coherency at the expense of retaining amplitude variations. The preprocessed data were exported in the Society of Exploration Geophysicists SEG-Y file format before being used in the Bauer and others (2013) program. Preprocessing steps and results are shown in figures 4-10.

We experimented with the order of these various preprocessing steps and discovered that the top mute must be applied before the AGC and TV spectral whitening functions in order for the signal amplitudes to properly normalize. Figure 10 illustrates the failure of normalization of wave amplitudes if AGC and TV spectral whitening are applied before the top mute. 

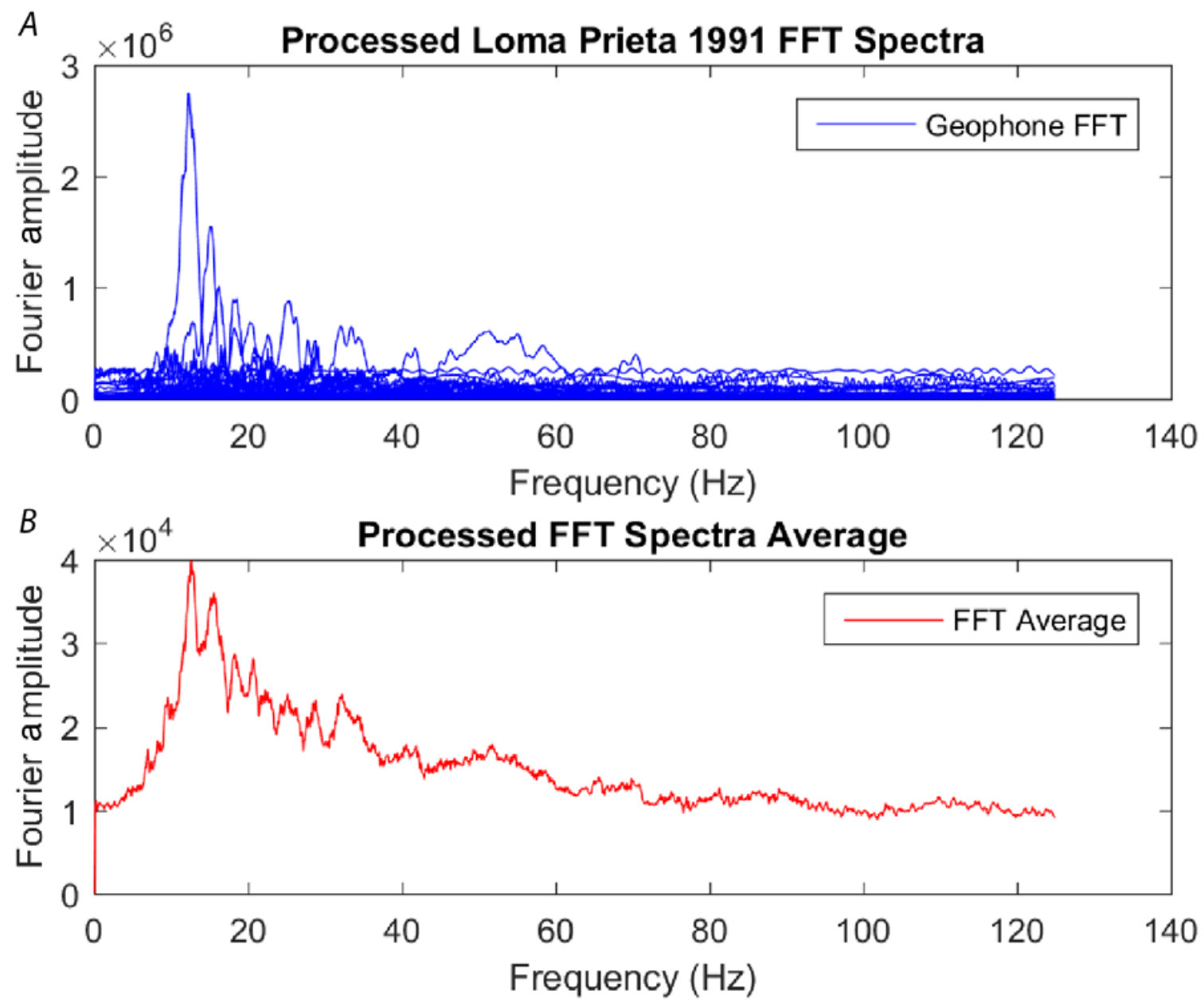

Figure 4. Graphs showing Fast Fourier transforms (FFTs) of data collected along the Loma Prieta profile (see fig. 1 for location). A, FFTs of raw data for each individual geophone, or station, and, $B$, the average FFT of spectra from all stations. The latter graph was used to choose a band-pass filter. $\mathrm{Hz}$, hertz. 


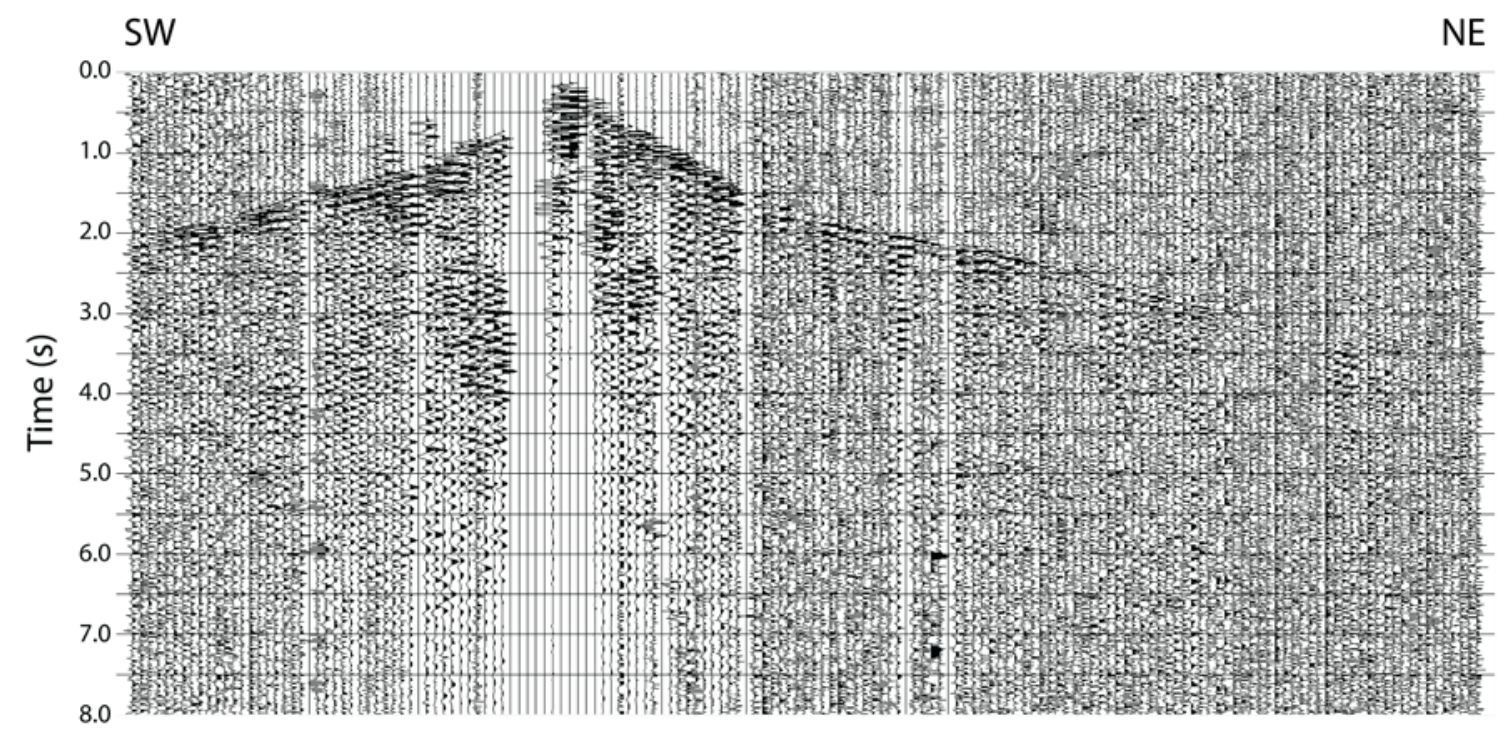

Figure 5. Plot showing unprocessed seismic data from shotpoint 8 of the Loma Prieta profile (see fig. 1 for location). The horizontal-axis is trace number (unlabeled). s, seconds; SW, southwest; NE, northeast.

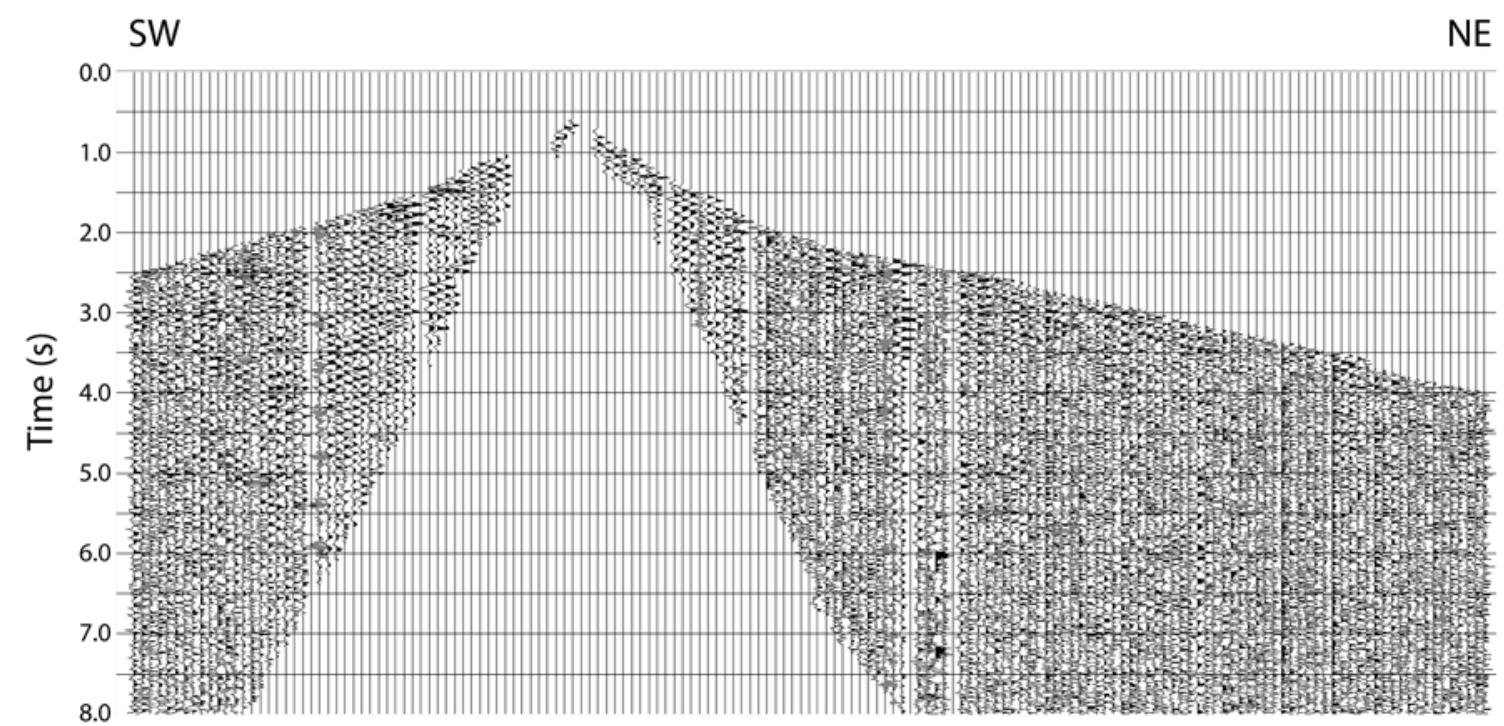

Figure 6. Plot showing top and bottom mutes applied to the shot gather of figure 5, to remove direct and refracted $\mathrm{P}$ waves, $\mathrm{S}$ waves, and surface waves. The horizontal-axis is trace number (unlabeled). S, seconds; SW, southwest; NE, northeast. 


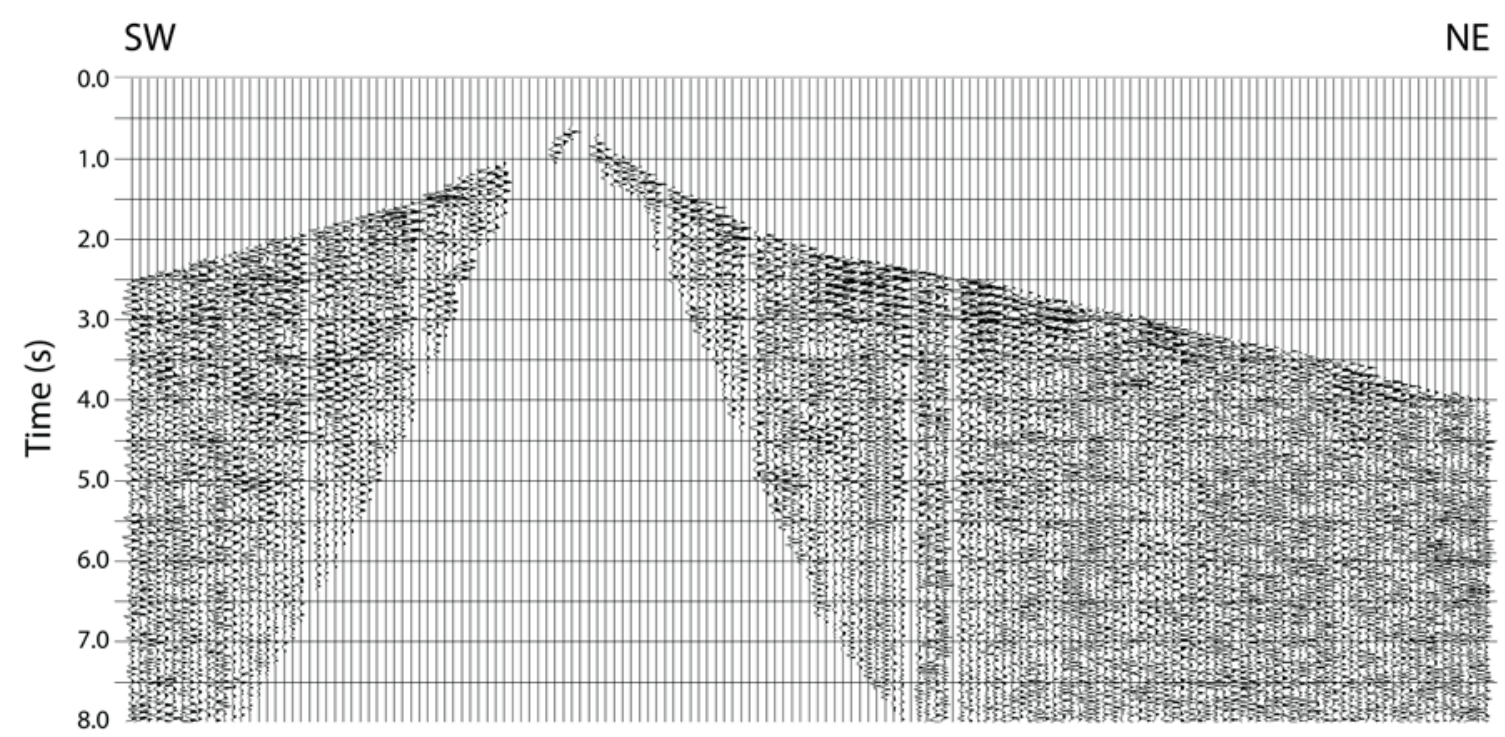

Figure 7. Plot showing bandpass filter $5-10-20-30 \mathrm{~Hz}$ and $60-\mathrm{Hz}$ notch filter applied to the shot gather of figure 6 . The horizontal-axis is trace number (unlabeled). s, seconds; SW, southwest; NE, northeast.

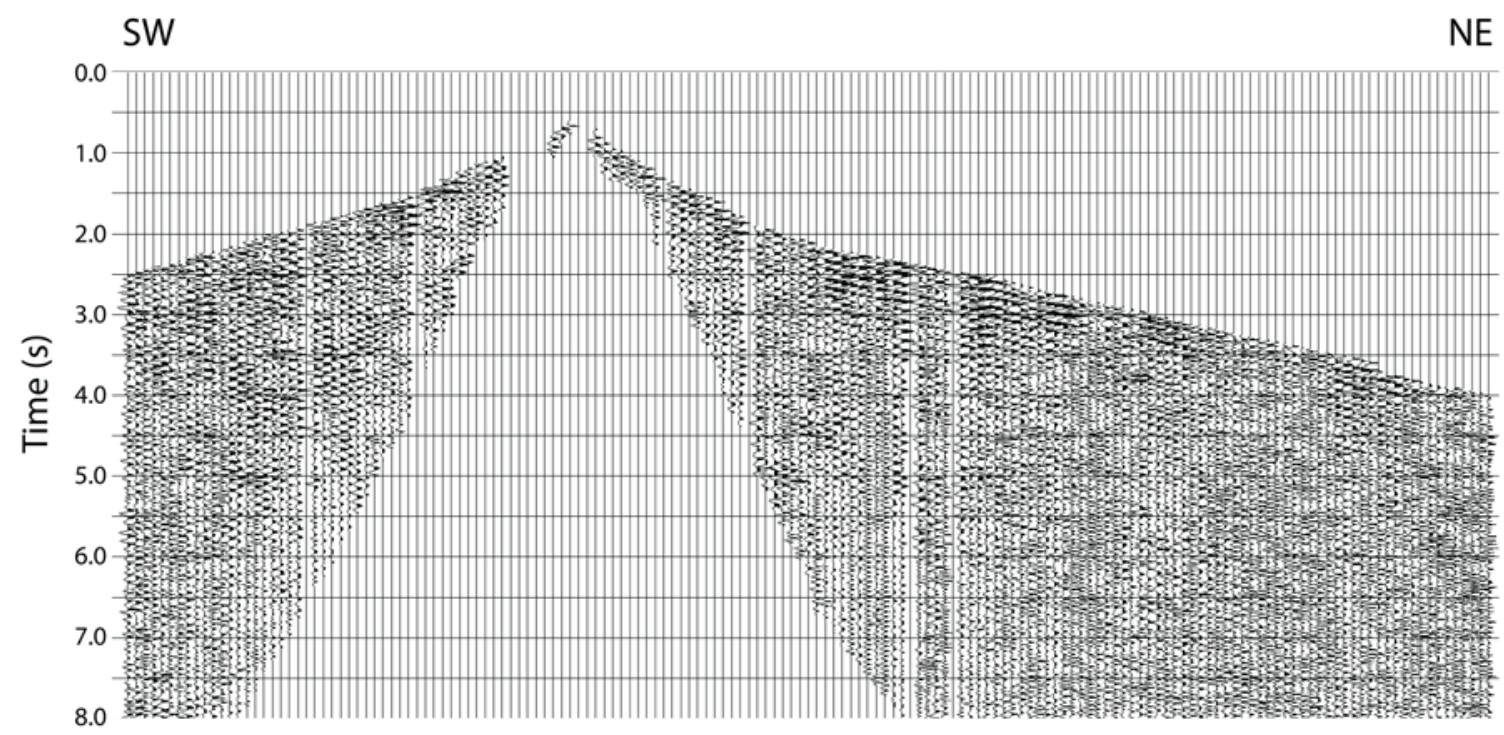

Figure 8. Plot showing automatic gain control, with an operator length of 500 milliseconds, applied to the shot gather of figure 7. The horizontal-axis is trace number (unlabeled). s, seconds; SW, southwest; NE, northeast. 


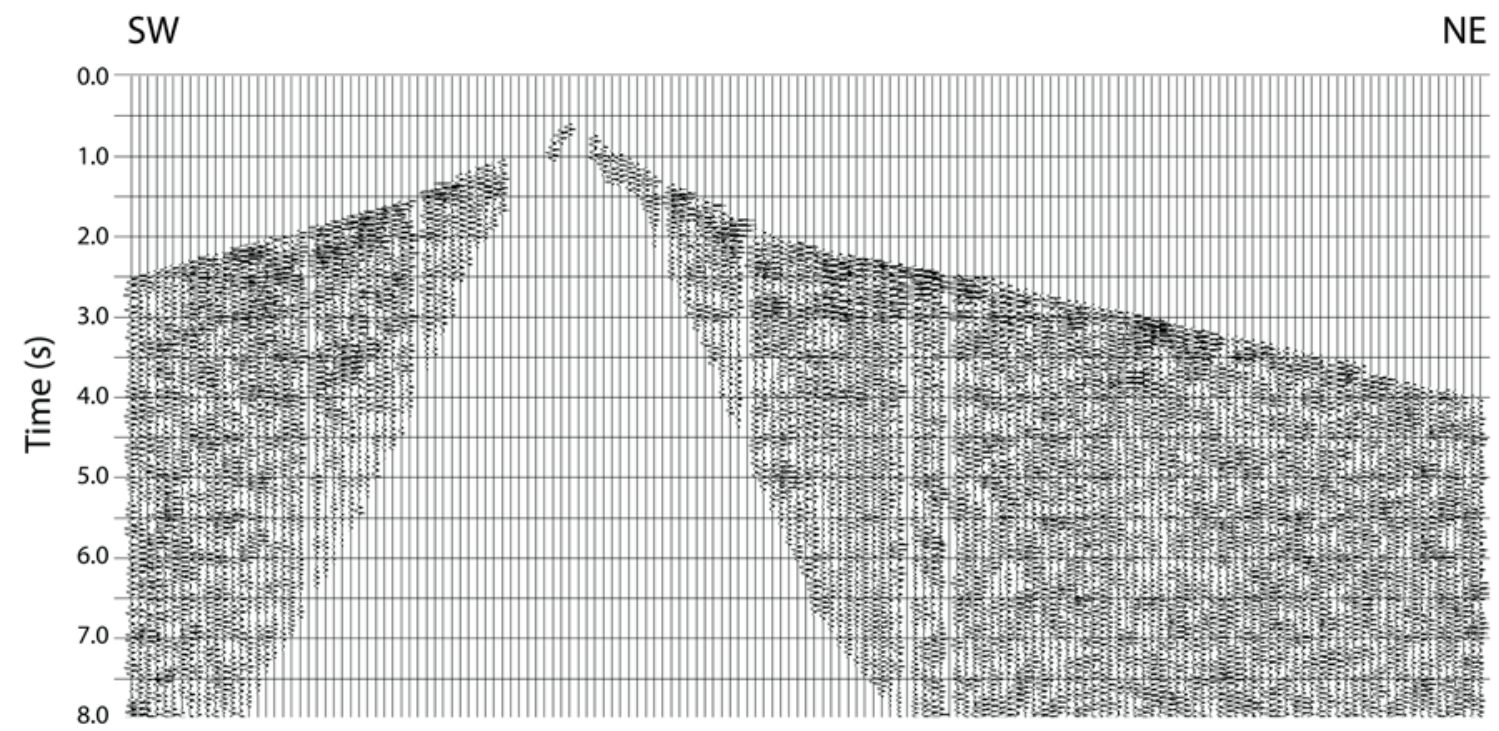

Figure 9. Plot showing time-variant spectral whitening applied to the shot gather of figure 8. The horizontal-axis is trace number (unlabeled). s, seconds; SW, southwest; NE, northeast.

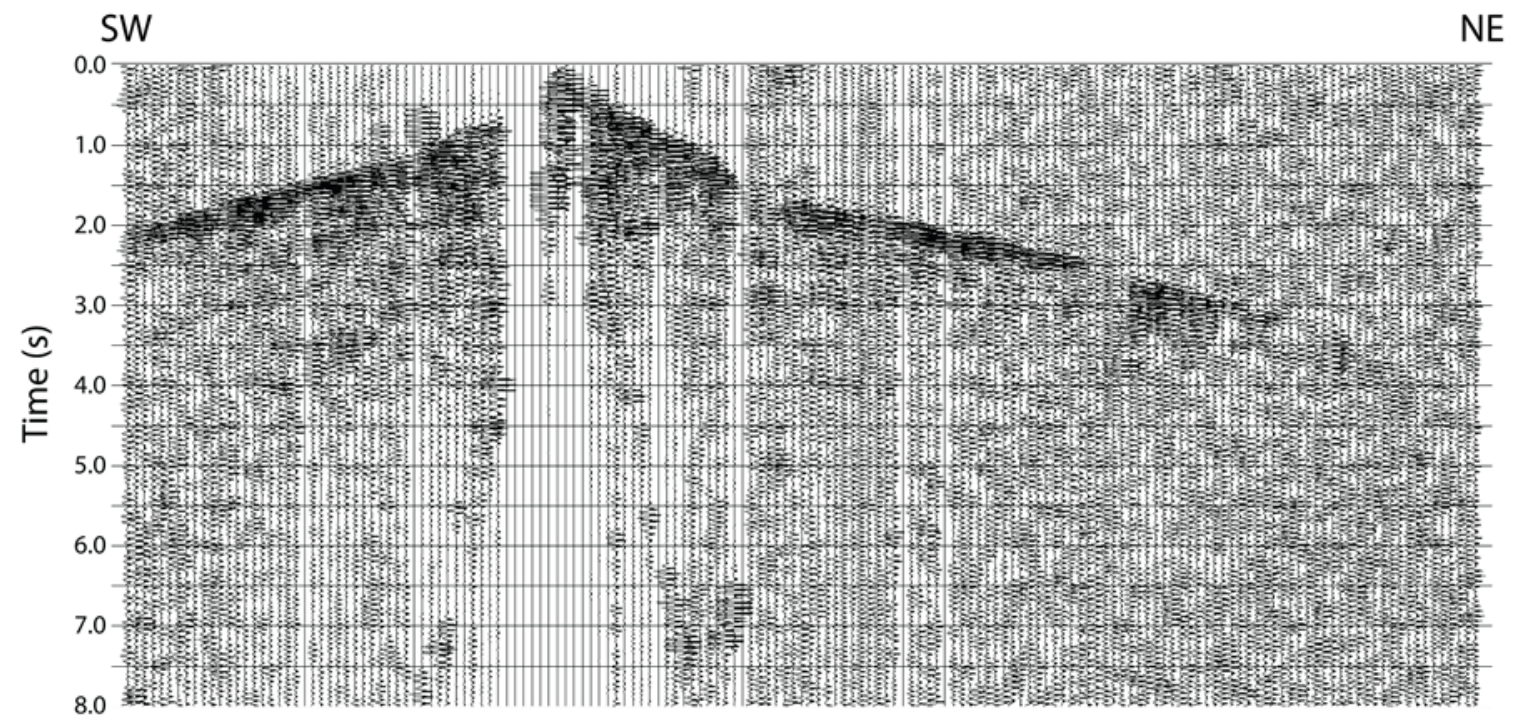

Figure 10. Plot showing all preprocessing applied to the shot gather of figure 5, without the top and bottom mutes. Notice that the direct and refracted wave signals dominate the shot gather, making it difficult to observe reflections in the first 3-4 seconds (s). The horizontal-axis is trace number (unlabeled). SW, southwest; NE, northeast.

\section{Processing Step 1}

The preprocessed data for each shot gather are input into "step 1" of the steep-dip migration algorithm of Bauer and others (2013), which finds wide-angle reflectors based on semblance and slowness and draws line vectors based on these detected phases. The minimum semblance threshold used was 0.6 out of 1.0, with only those normalized trace amplitudes greater than 0.2 (out of 1.0) contributing to the semblance. The maximum slowness was set to -0.30 second per kilometer ( $/ \mathrm{km}$ ); the negative sign selects reverse-moveout reflections (Bauer and others, 2013). Commonly, reverse- 
moveout reflections have migrated dips greater than 45 degrees, and we refer to them as steep reflections.

The shot gather for shotpoint 8 (SP8) is repeated in the top panel of figure 11. Reflection lines selected by the above criteria are shown in the second panel. Note that these reflections are not always easily evident to the eye, as they cross stronger direct and forward-scattered energy. Automatic detection is required. Other reverse-moveout phases are also apparent in the second panel of figure 11, but these do not meet the criteria outlined above. Similar images are shown for SP3 (fig. 12, top and second panels). 


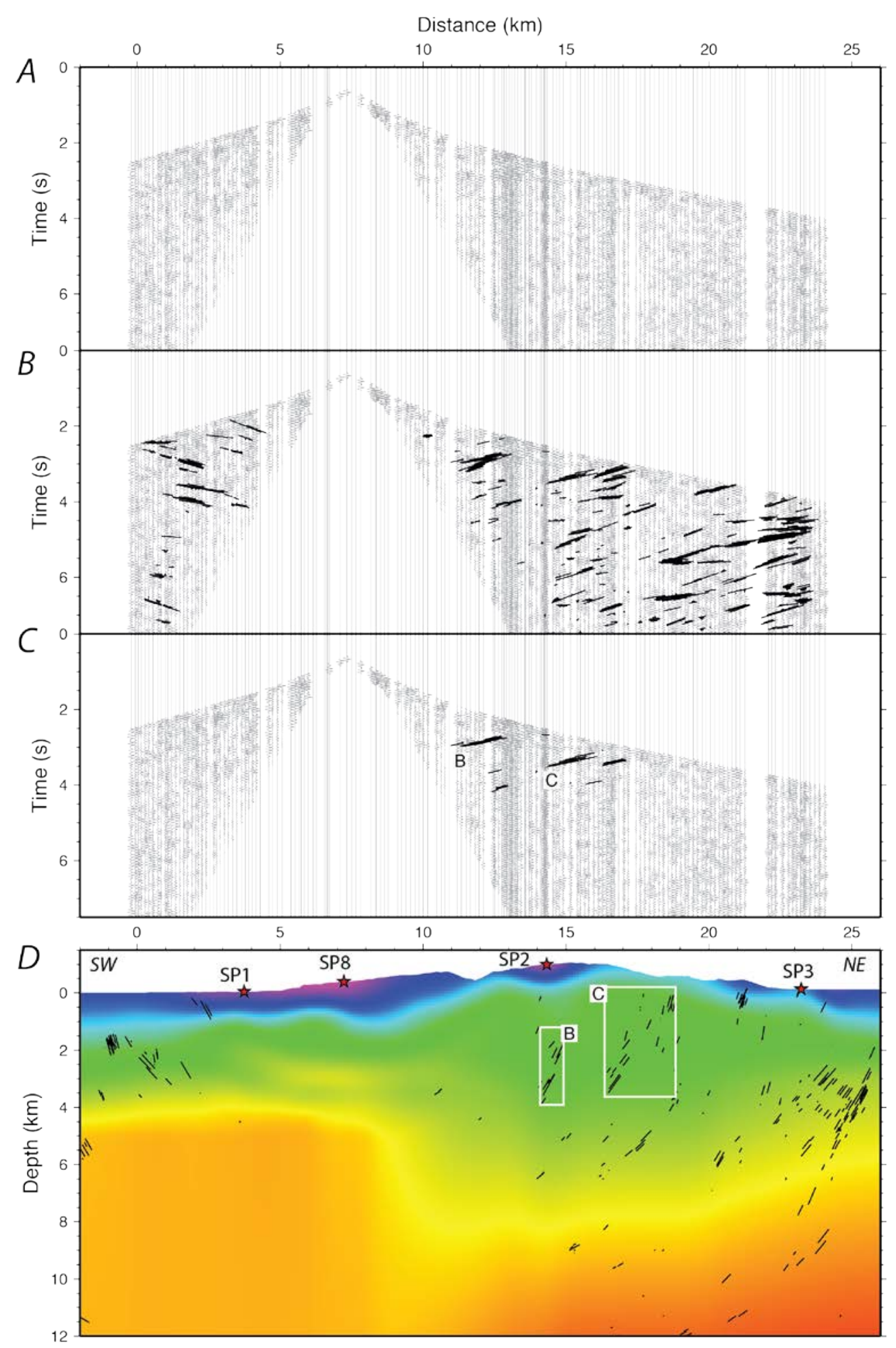

Figure 11. Illustrations showing reverse-moveout reflections picked on the preprocessed shot gather from shotpoint 8 of the Loma Prieta profile (see fig. 1 for location) and migration of these reflections in the depth domain. $A$, Preprocessed data; $B$, line vectors (reflections) found from semblance analysis and reverse-moveout filtering described in the text (step 1); $C$, subset of reflections that migrate to within boxes $B$ and $C$ in the bottom (fourth) panel; and $D$, migrated reflections from the second panel. km, kilometers; s, seconds; SW, southwest; NE, northeast. 


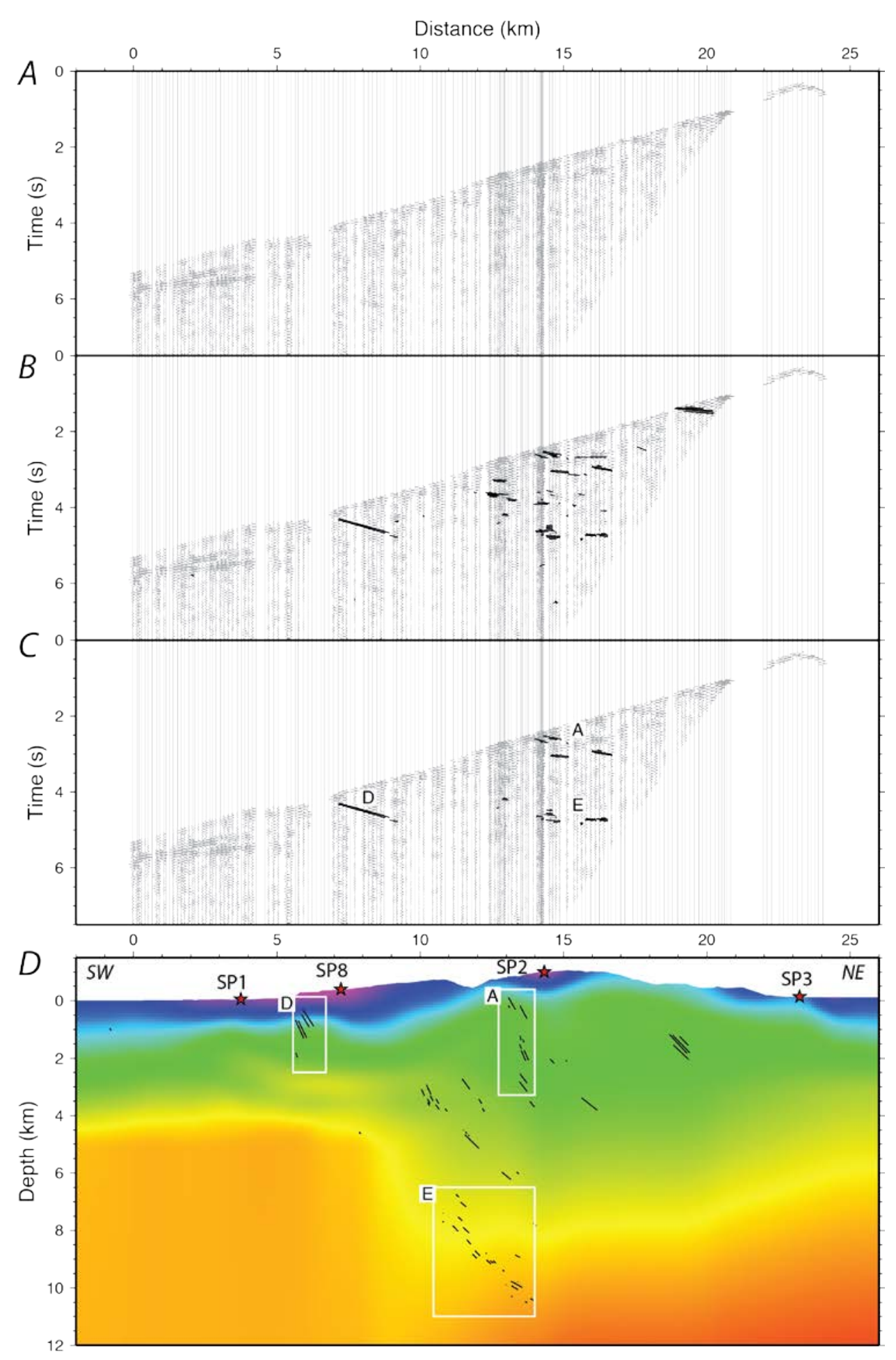

Figure 12. Illustrations showing reverse-moveout reflections picked on the preprocessed shot gather from shotpoint 3 of the Loma Prieta profile (see fig. 1 for location) and migration of these reflections in the depth domain. $A$, Preprocessed data; $B$, line vectors (reflections) found from semblance analysis and reverse-moveout filtering described in the text (step 1); $C$, subset of reflections that migrate to within boxes A, D, and E in the bottom (fourth) panel; and $D$, migrated reflections from the second panel. km, kilometers; s, seconds; SW, southwest; NE, northeast. 


\section{Processing Step 2}

For processing step 2, the user selects a velocity model, which generates an $x-z$ plot and outputs grid-space parameters for the migration model. The velocity model of figure $2 B$ was used. The velocitymodel grid spacing was resampled at $0.1 \mathrm{~km}$ horizontally and vertically for sufficient resolution in the migrating process.

\section{Processing Step 3}

For processing step 3, the output reflectors selected in step 1 were migrated, using the migration algorithm described in Bauer and others (2013), to their correct locations using the velocity model from step 2 (see bottom panels [parts D] of figs. 11 and 12). See appendix 2 for description of the migration method.

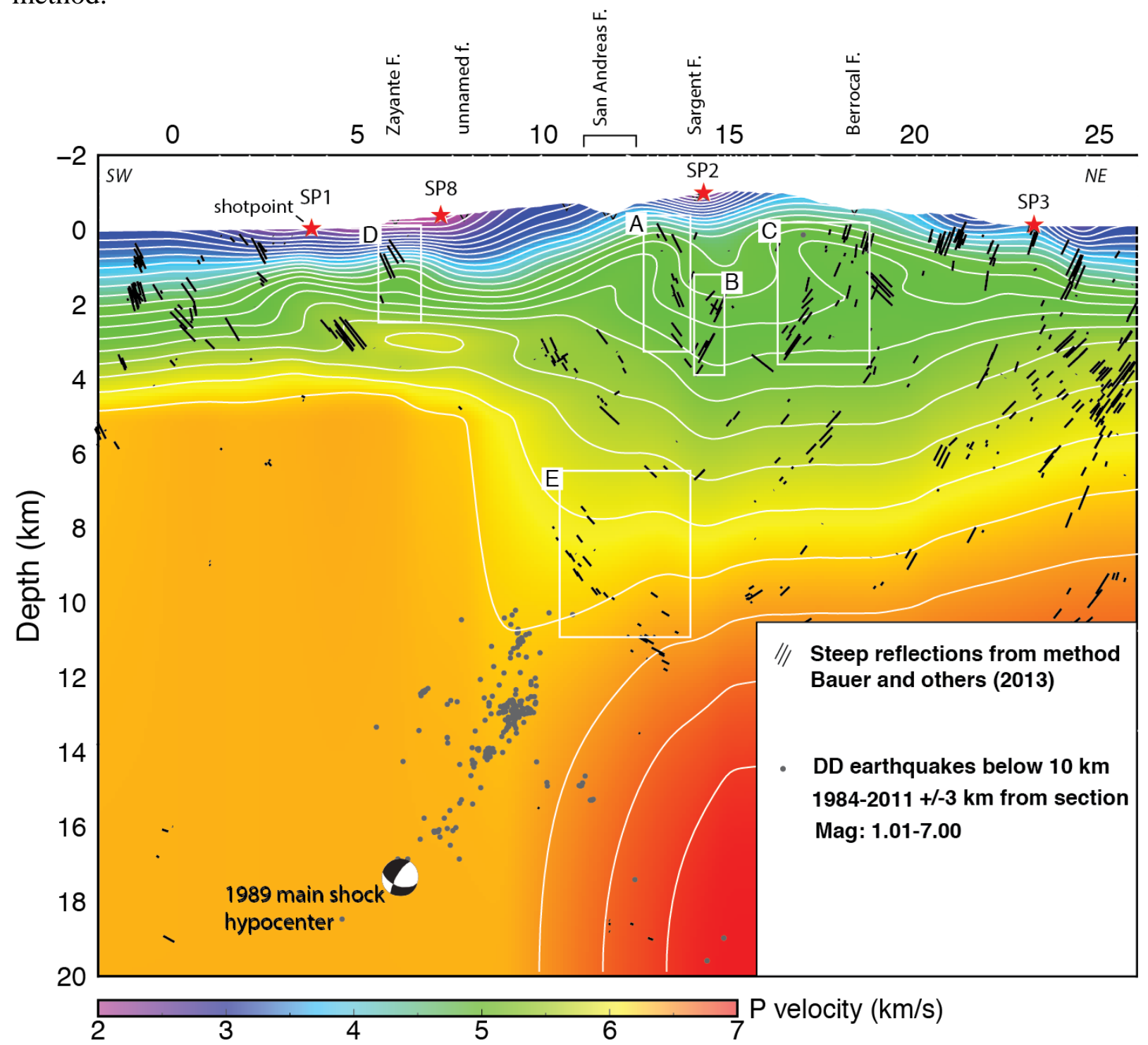

Figure 13. Illustration showing final output of migrated reverse-moveout reflections for all 4 shotpoints of the Loma Prieta profile (see fig. 1 for location). Contour interval 0.2 kilometer per second (km/s) (see fig. 2B). See text for description of boxes A-E. km, kilometers; F., Fault; SW, southwest; NE, northeast; DD, relocated earthquakes from double-difference and wave-form cross-correlation methods; Mag., magnitude; $P$, compressional wave. 
Multiple iterations of the data preprocessing and processing through the three steps were run to find the best parameters for the clearest and most interpretable results for the steep reflections. The most interpretable results were judged to be those that yielded reflection packages that were consistent with relocated hypocenter patterns (figs. $3 A$ and $B$ ), potential-field modeling (see below), and geologic mapping of surface fault traces (SAF, Sargent, Berrocal, and Zayante Faults; see McLaughlin and Clark, 2004). Note that reflections SW of SP1, where there is significant curvature in our profile, are not interpreted in this study.

Reflections are generated by interfaces between rocks of differing seismic impedance, which is a function of seismic velocities and densities. A greater seismic-velocity (or density) contrast generates a higher amplitude reflection (see, for example, Lay and Wallace, 1995). Higher velocity contrasts are generally seen at faults, where quite different rock types can be juxtaposed. However, more importantly, fault zones can host low-velocity breccia and gouge that differ significantly in velocity and density from that of the host rocks on either side. See the synthetic example in appendix 2, where a narrow fault zone (white line) is embedded in a velocity model, generating a high-amplitude reflection. Ryberg and Fuis (1998), Bleibenhaus and others (2007), and Bauer and others (2013) present real examples of fault-zone reflectivities. Velocity contrasts between fault-zone rocks and host rocks can exceed $2 \mathrm{~km} / \mathrm{s}$, whereas contrasts among different kinds of sedimentary, igneous, and metamorphic rocks are generally much smaller (for the latter see Clark, 1966). Finally, the reflections we interpret below are correlated with aftershocks, making it likely that these reflections were generated in active fault zones.

Boxes A-E have been drawn around reflections of interest (fig. 13; see also figs. 11 and 12). Box A contains steeply northeast-dipping reflections located a couple of kilometers north of the surface trace(s) of the SAF. Near the surface, these reflections curve southwestward toward those SAF trace(s) and are possibly interpretable as reflections from the SAF. This curving pattern is similar to the geometry of the SAF modeled from potential-field data (see below). Box B contains steeply southwestdipping reflections approximately beneath the surface trace of the Sargent Fault, which may be interpretable as reflections from that fault. Box $\mathrm{C}$ contains a zone of steeply to moderately southwestdipping reflections that projects to the surface at approximately the trace of the Berrocal Fault. Box D contains a zone of steeply northeast-dipping reflections close to the surface trace of the Zayante Fault. Box E contains a diffuse zone of sparse, short reflections at 7- to 10-km depth that would appear to cross any deep projection of the SAF from box A to the main rupture of the Loma Prieta earthquake below 10-km depth. If these represent a fault, they present a problem in interpreting a connection of the SAF to the Loma Prieta rupture. Alternatively, they may represent reflections from other geologic features or noise.

\section{Previous Modeling of Aeromagnetic Data}

Two aeromagnetic profiles, E-E' and S-S', modeled by Jachens and Griscom (2004), are of interest in our study (figs. 1 and 14). Profile E-E', approximately $5 \mathrm{~km}$ southeast (SE) of the Loma Prieta profile, shows a well-controlled shape of the SAF in the upper $2 \mathrm{~km}$ or so (fig. 15) that has a NE curvature similar to that seen in our steep reflections (fig. 13, box A). Profile S-S', approximately 30 $\mathrm{km}$ SE of our Loma Prieta profile, shows a subsurface geometry of the SAF that is well constrained from both magnetic data and aftershocks from near the surface to a depth exceeding $10 \mathrm{~km}$ (fig. 16). Thus, on profile S-S', the Loma Prieta rupture, as outlined by aftershocks, appears planar and continuous from the surface trace of the SAF into the mid crust, with a steep SW dip. These two profiles support our interpretations that (1) the northeastward curvature interpreted in the upper few kilometers of the SAF in our reflection study (fig. 13) is real, consistent with the geometry on profile E-E', and (2) the Loma Prieta rupture, which dips moderately to steeply SW, is the SAF, consistent with the geometry on 
profile S-S'. The unexpected NE curvature in the upper few kilometers is part of an overall steep dip of the SAF in the upper crust. The NE curvature may be caused by shallow detachment faults or landsliding that has deformed the SAF by southwestward movement of near-surface rocks (McLaughlin and Clark, 2004).

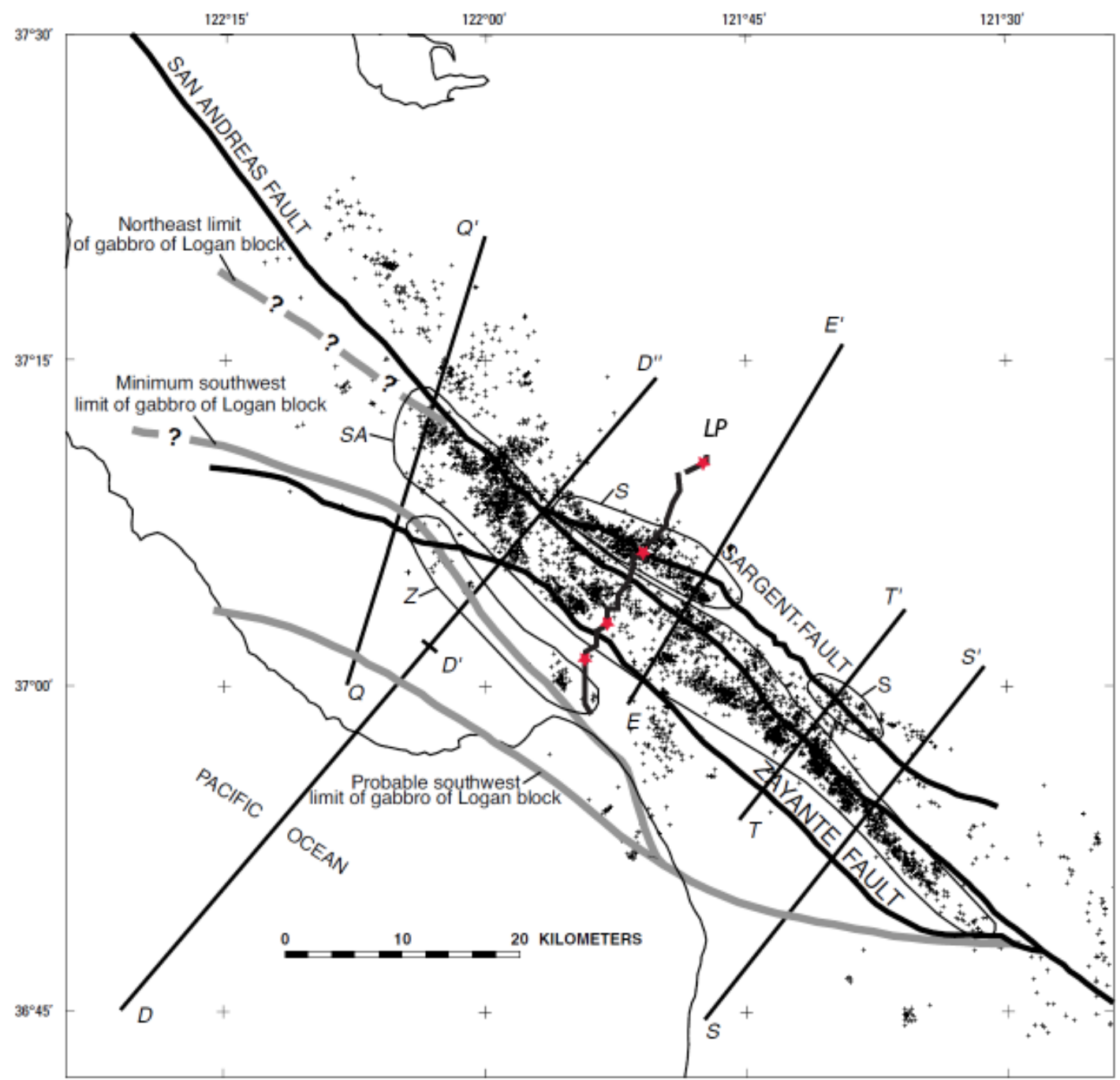

Figure 14. Map of the Loma Prieta region, California, from Jachens and Griscom (2004; their fig. 11), showing distribution of aftershocks of the 1989 Loma Prieta earthquake (plus signs; October 18, 1989, through 1991). The map also shows locations of major faults, and potential-field profiles. LP, Loma Prieta seismic profile. 

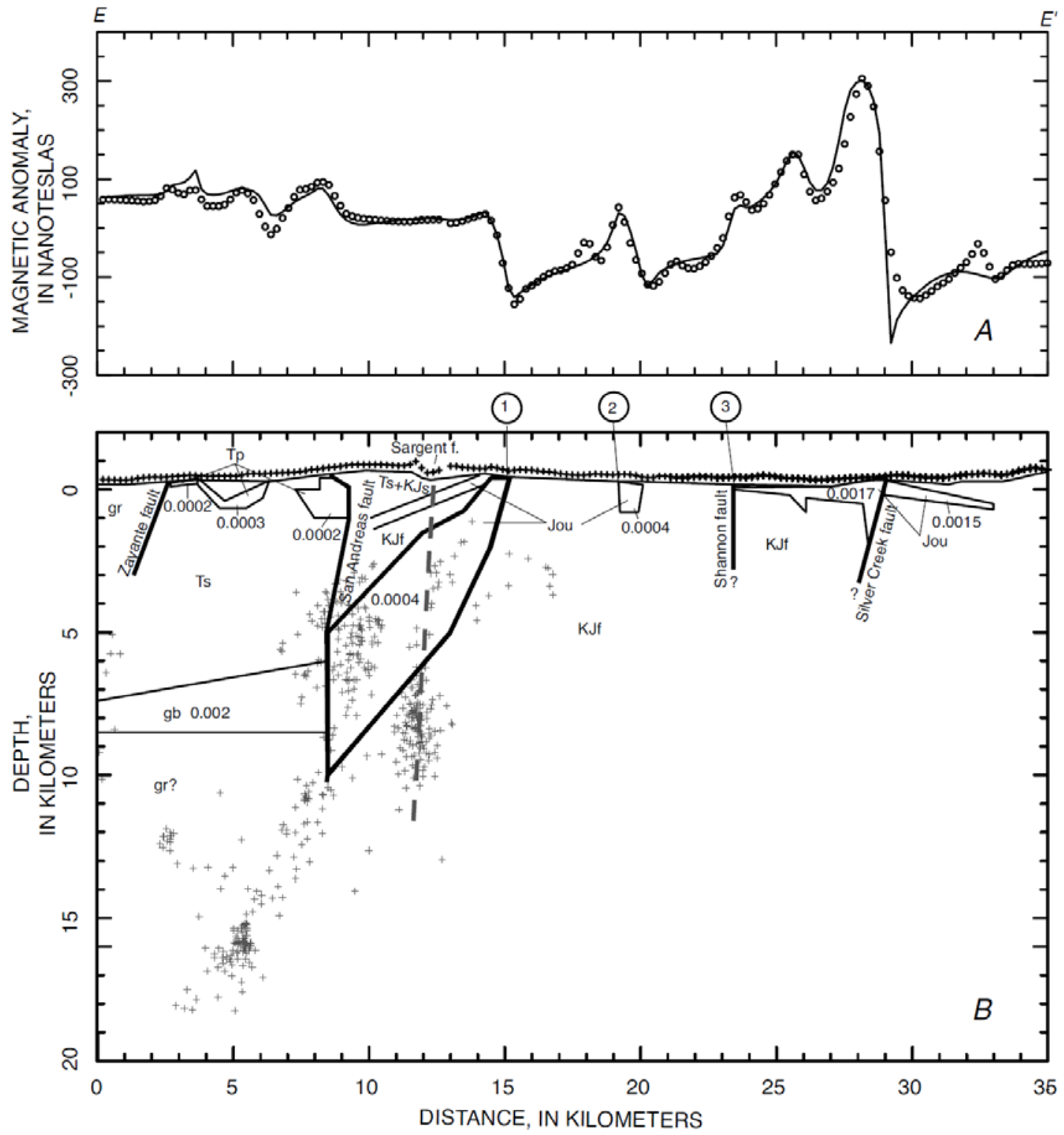

Figure 15. Illustration from Jachens and Griscom (2004; their fig. 13) showing magnetic data and modeling along profile E-E' (see fig. 14 for location). Gridded observations, small circles; solid line, calculated magnetic anomaly. Note the northeast dip in the upper 1 kilometer of the San Andreas Fault (SAF). Numbers on units are magnetizations in electromagnetic units per cubic centimeter. Aftershocks of the 1989 Loma Prieta, California, earthquake are shown (plus signs; Oct 18, 1989, through 1991). gb, gabbro; gr?, granitic rocks?; Jou, Jurassic ophiolitic rocks undivided; KJf, Cretaceous and Jurassic Franciscan complex; Tp, Tertiary (Pliocene) sedimentary rocks; Ts, Tertiary sedimentary rocks. 

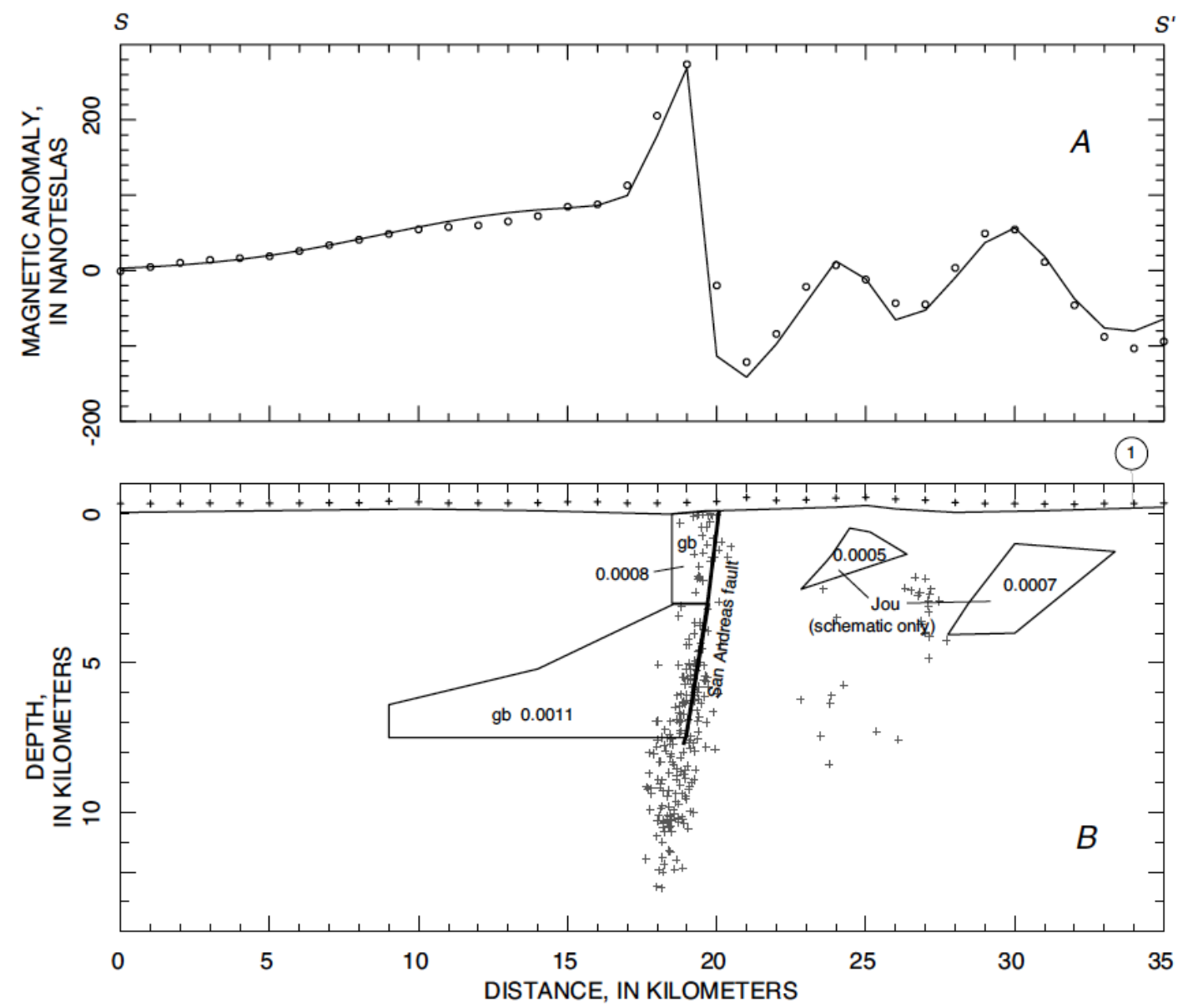

Figure 16. Illustration from Jachens and Griscom (2004; their fig. 15) showing magnetic data and modeling along profile S-S' (see fig. 14 for location). Note that the subsurface shape of the San Andreas Fault (SAF) is well controlled by both magnetic and aftershock data. Here, the SAF is continuous and planar from its surface trace downward. Numbers on units are magnetizations in electromagnetic units per cubic centimeter. Aftershocks of the 1989 Loma Prieta, California, earthquake are shown (plus signs; Oct 18, 1989, through 1991). gb, gabbro; Jou, Jurassic ophiolitic rocks, undivided.

\section{Interpretation}

Previous interpretations of subsurface fault structure in the vicinity of the 1989 Loma Prieta earthquake allowed a connection from the surface trace of the SAF and other splay faults to the mainshock rupture in the middle crust, but these preferred that the mainshock rupture occurred on a secondary fault within the San Andreas Fault Zone. In this study we prefer an interpretation of a direct connection: the mainshock rupture occurred on the SAF itself.

\section{Previous Interpretations}

Dietz and Ellsworth $(1990,1997)$ constructed two alternate interpretations of subsurface fault structure in the Loma Prieta area based on NCSN aftershock distributions and focal mechanisms, which are summarized in figure 17. In the first interpretation, the Loma Prieta rupture truncates a vertical SAF; in the second, the rupture is the SAF and changes dip at 6-km depth. Bürgmann and others (1997) modeled afterslip deformation following the Loma Prieta earthquake with slip on both the main rupture 
below 10-km depth and on the Berrocal Fault in the upper few kilometers. However, Bürgmann and others (1997) did not infer a kinematic connection between these two ruptures.

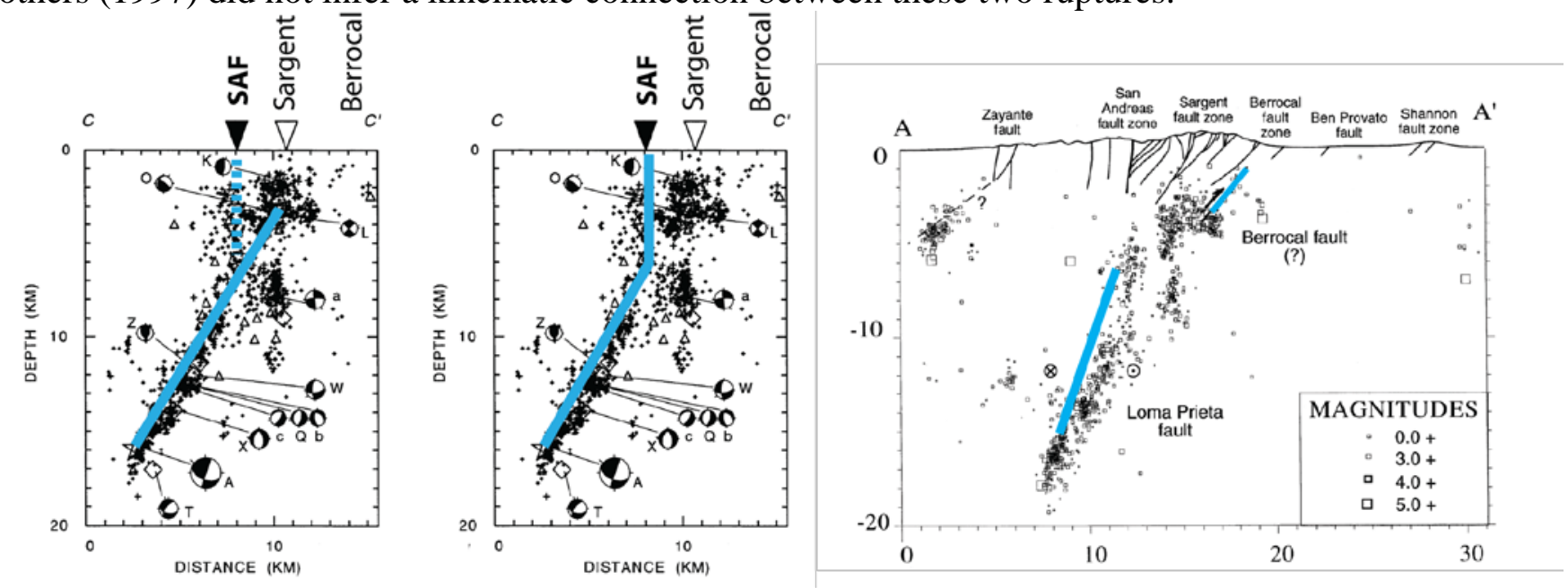

$A$

$B$

Figure 17. Illustrations showing previous rupture interpretations for the 1989 Loma Prieta, California, earthquake by Dietz and Ellsworth (1990) and Bürgmann and others (2004) (solid blue lines). A, Two fault interpretations from Dietz and Ellsworth (1990), based on Northern California Seismic Network hypocenters and focal mechanisms. In the left diagram, the rupture truncates a vertical San Andreas Fault (SAF). In the right diagram, the rupture is the SAF and changes dip at depth of $\sim 6$-kilometers (KM). B, Fault interpretations by Bürgmann and others (2004; their figure $11 \mathrm{~A}$ ) based on afterslip deformation. Solid blue lines are overlain on rupture planes interpreted by these authors for clarity.

\section{Interpretation from Steep Reflections, Relocated Earthquakes, and Potential Field Analysis}

Our analysis of reflections produces at least three reflection packages that we consider robust (fig. 13, boxes $A-C$; fig. 18). These are considered robust because (1) they are similar in geometry to relocated aftershock clusters (figs. 3,19), and (2) they are similar in geometry to interfaces modeled from potential-field data (fig. 15). The interpreted SAF has a NE curvature (dips initially NE in cross section) in all three datasets. The interpreted Sargent Fault also curves slightly northeastward in the reflection and relocated aftershock images, although it is not modeled in the potential-field data. The Berrocal Fault has the same approximate subsurface location in all three datasets. Note that the relocated aftershock clusters, on which these three fault interpretations are based, may move around as much as a kilometer, depending on the velocity model used for relocation, allowing for better or worse agreement with fault locations inferred from our reflection analysis. Currently, below a depth of 1-2 km, they are displaced about $1 \mathrm{~km} \mathrm{SW}$ from the faults interpreted from steep reflections (see the cover illustration).

There may be additional faults that correlate with our steep reflections, including the Zayante Fault (fig. 13, box D; fig. 18), an unnamed fault at 8-km model coordinate, and one or more unspecified faults northeast of the Berrocal Fault (fig. 18, dashed gray lines). However, the evidence is not strong for these faults. The apparent northeastward dip of the Zayante Fault, for example, is not consistent with the southwestward dip inferred from potential-field data (fig. 15). 


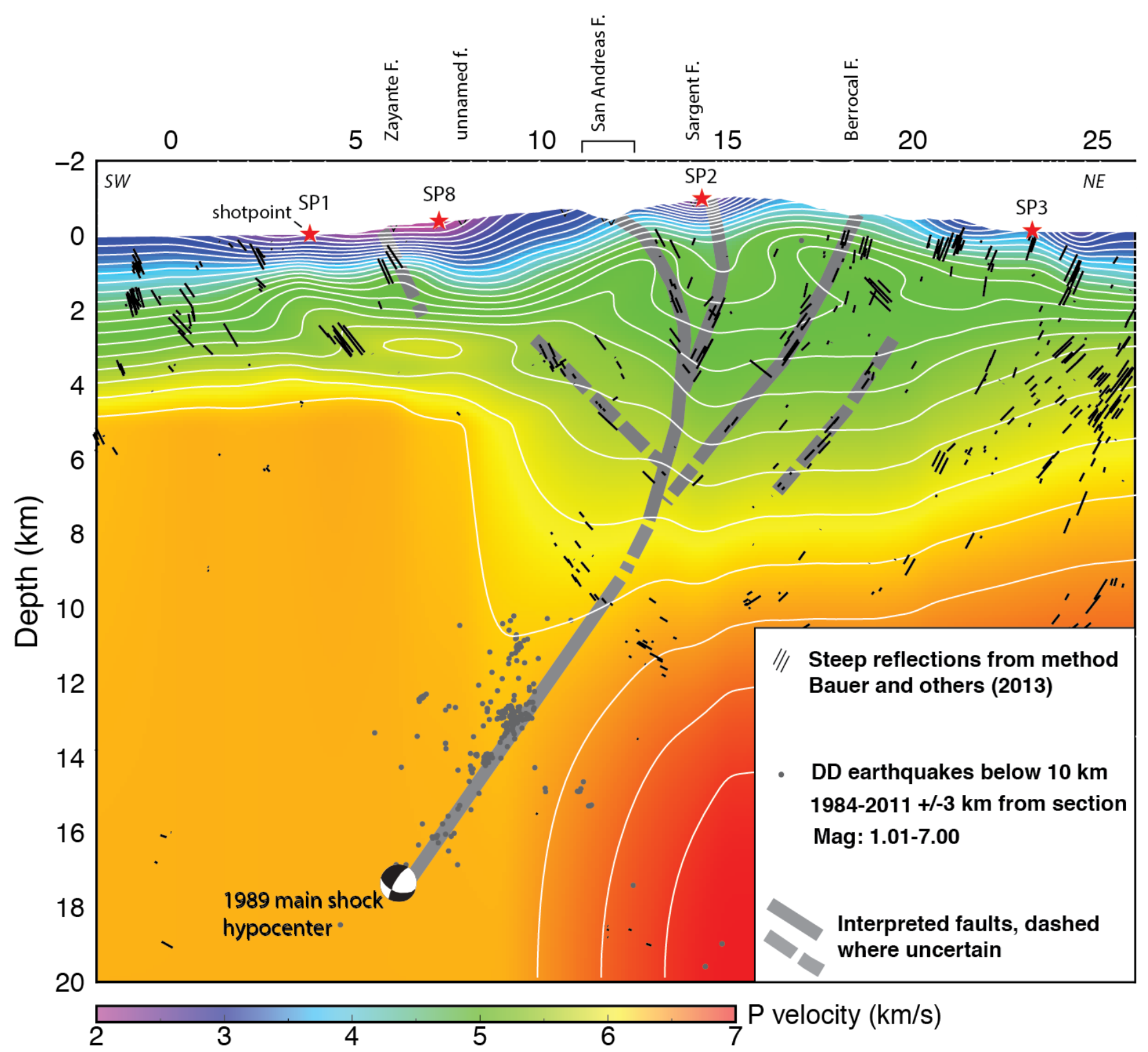

Figure 18. Illustration showing fault interpretations for the 1989 Loma Prieta, California, earthquake from seismicreflection data of this study (see fig. 1 for location). Contour interval 0.2 kilometers per second (km/s) (see fig. 2B). km, kilometers; F., Fault; SW, southwest; NE, northeast; DD, relocated earthquakes from double-difference and wave-form cross-correlation methods; Mag., magnitude; $P$, compressional wave. 


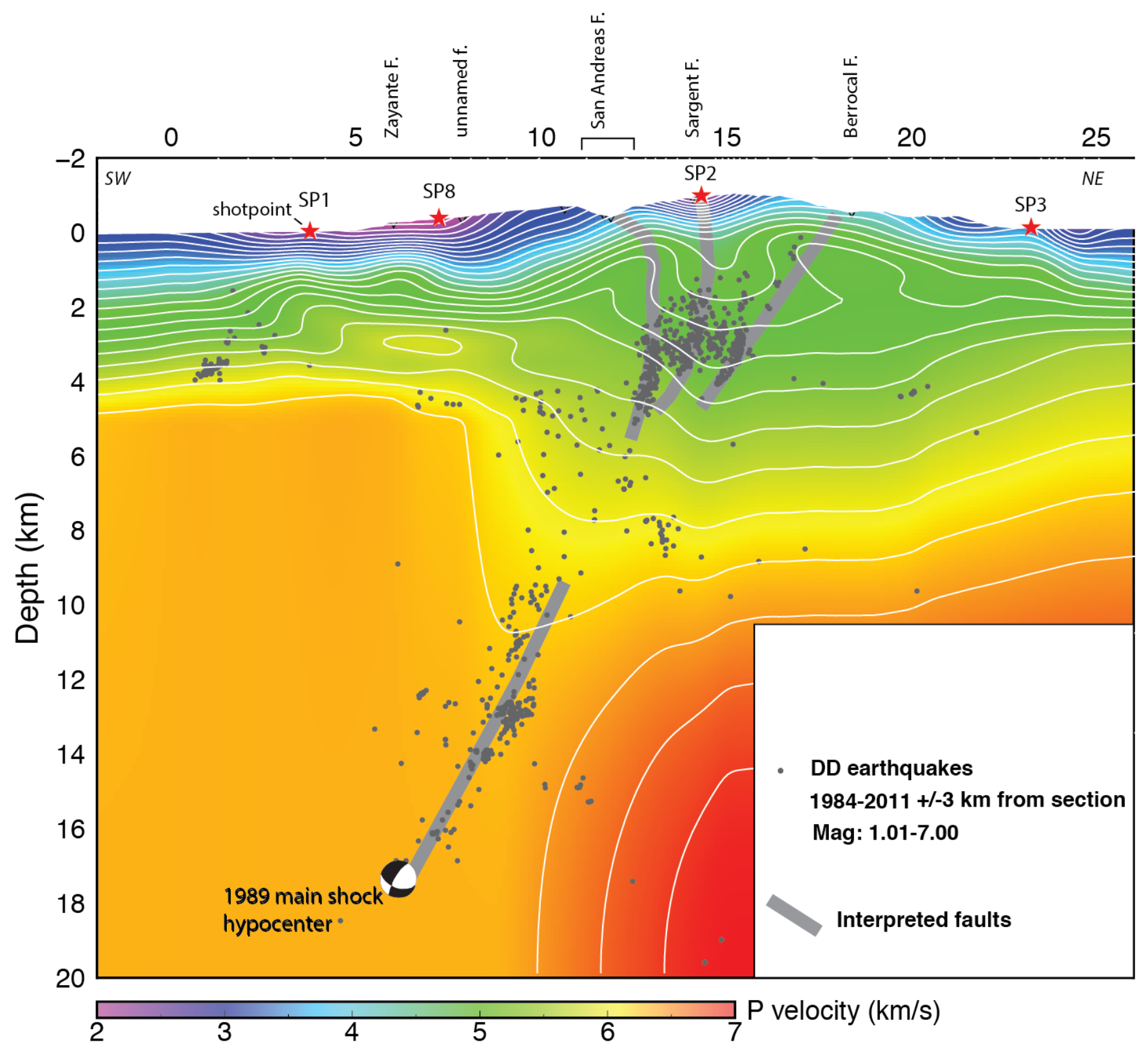

Figure 19. Illustration showing fault interpretations for the 1989 Loma Prieta, California, earthquake from relocated aftershocks from this study (see fig. 1 for location). This is identical to figure $3 B$ but is repeated for easier comparison with figure 18. Fault geometries from figures 18 and 19 are compared directly in the cover illustration. km, kilometers; km/s, kilometers per second; F., Fault; SW, southwest; NE, northeast; DD, relocated earthquakes from double-difference and wave-form cross-correlation methods; Mag., magnitude; $P$, compressional wave.

\section{Tectonics}

Deformation during the Loma Prieta mainshock was dominantly strike-slip SE of the epicenter and oblique-partially compressional slip-northwest (NW) of the epicenter (Dietz and Ellsworth, 1990, 1997; Eberhart-Phillips and Michael; 1998, 2004). A nonplanar rupture is postulated in this study in the vicinity of the epicenter. Judging from the seismicity cross sections in Dietz and Ellsworth (1997), the rupture plane may remain nonplanar for a distance of $30 \mathrm{~km}$ NW of the epicenter, where the 
aftershock alignment does not project to the surface trace of the SAF. On the other hand, the rupture may become largely planar at a distance of $30 \mathrm{~km} \mathrm{SE}$ of the epicenter (see fig. 16). A southwestward bend of the SAF in plan view as one progresses from SE to NW along the fault appears correlated with the onset of nonplanar geometry (see Dietz and Ellsworth, 1997, their fig. 27).

Both strike slip and dip slip can be accommodated on nonplanar faults. No deformation of the rocks on either side of the fault is required for strike slip on a nonplanar fault, where the loci of dip changes are parallel to the slip direction. However, deformation on one or both sides is required in general for oblique slip on a nonplanar fault. For example, nonplanar faults are commonly seen in foldand-thrust belts, with most deformation occurring in the hanging wall ("ramp-and-flat" fault geometry). Deformation during the Loma Prieta rupture involved uplift on the hanging wall, mainly NW of the epicenter where oblique slip occurred (Marshall and Stein, 1997).

\section{Comparison with SAF Structure in Coachella Valley}

The SAF in the northern Salton Trough, or Coachella Valley, in southern California, appears nonvertical and nonplanar (fig. 20). In cross section, it consists of a steeply dipping segment ( $75^{\circ} \mathrm{dip}$ $\mathrm{NE}$ ) from the surface to 6-km depth and a moderately dipping segment below 6-km depth (50-55 dip $\mathrm{NE}$ ). It also appears to branch upward into a flower-like structure beginning below about 10 -km depth. The flower-like fault geometry is seen mainly in the hanging wall of the SAF. This geometry is seen on two lines in the Coachella Valley; line 4 is shown in figure 20. Images of the SAF Zone in the Coachella Valley were constructed, as in this study, from analysis of steep reflections, hypocenters, and potentialfield models (Fuis and others, 2017). 


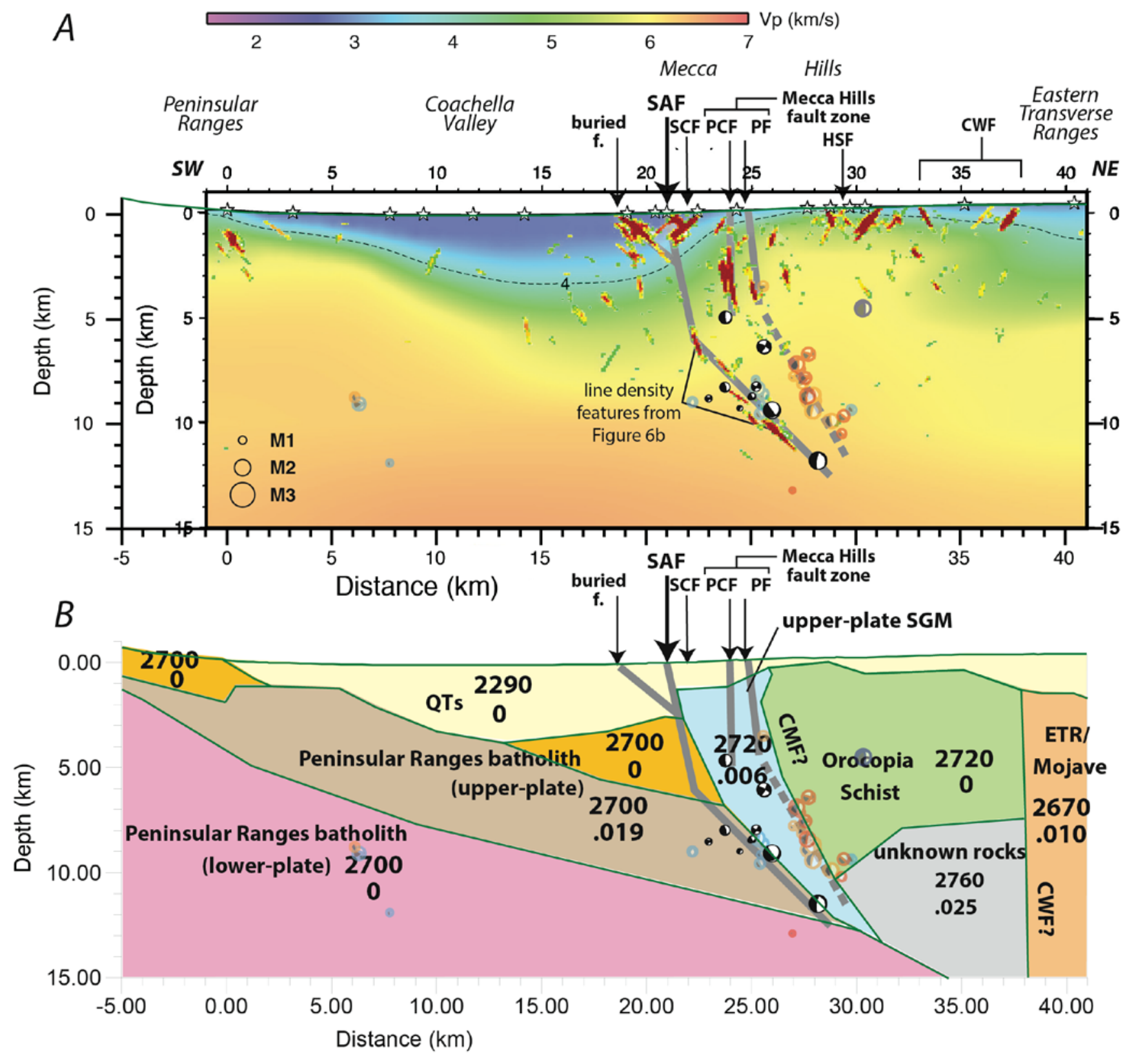

Figure 20. Illustration showing nonplanar San Andreas Fault and flower-like structure imaged in the Coachella Valley of southern California by Fuis and others (2017; line 4; their figs. 6c, d). Line 4 is oriented southwest (SW)northeast (NE) across the Salton Trough near the northwest end of the Salton Sea. A, Velocity model for line 4 with reflection-line-density features shown as small lenticular red and yellow features, and interpreted faults (heavy gray lines). (Reflection line density is the number of migrated reflection line segments in 100×100-meter grid cells weighted by their underlying waveform coherencies-see Fuis and others, 2017). Vp, P-wave velocity; white stars, shotpoints; M, magnitude. Far-hemisphere focal mechanisms (fm) from Yang and others (2012) using hypocenters of Hauksson and others (2012): black, fm within 2 kilometers (km) of line 4; dim gray and blue, fm from 2-10 km NW of line 4; dim orange and red, fm from 2-10 km southeast of line 4. Focal mechanisms are from the period 
1981 to 2011. The focal mechanism solutions displayed are from the 3 highest-quality categories (A, B, C) of Yang and others (2012). CWF, Clemens Well Fault (buried), PCF, Painted Canyon Fault; PF, Platform Fault; SAF, San Andreas Fault; SCF, Skeleton Canyon Fault. B, Joint model of gravity and magnetic data along line 4. Interpreted faults (gray) and fm are repeated from $A$. Density (top numbers, in kilograms per cubic meter); magnetic susceptibility (bottom numbers, in 10-3 International System units). QTs, Quaternary-Tertiary sediments; CMF?, Chocolate Mountains Fault? (buried, overturned?); ETR, Eastern Transverse Ranges rocks; and SGM, San Gabriel Mountains rocks (see Powell, 1993). For data fits see Fuis and others (2017). $A$ and $B$ both show that the deep part of the SAF dips moderately NE, with a flower-like structure, consisting of steeply dipping faults, developed above this zone, including the Painted Canyon and Platform Faults and possibly a buried fault at $18.5-\mathrm{km}$ range. The upper, steeply dipping part of the SAF (above $\sim 6-\mathrm{km}$ depth) is neither imaged by reflections or earthquakes. Its connection to the deeper, moderately dipping fault is inferred from its surface trace and the deeper reflection pattern.

We compare our interpreted fault structure at Loma Prieta with that of the Coachella Valley's line 4 in figure 21 (Coachella Valley fault dips are reversed in this figure). In both cases, the upper part of the SAF dips steeply and the lower part (below 6-km depth) dips moderately. In both cases, the flower-like structure is seen chiefly in the North American Plate, which is the hanging wall in the Coachella Valley and the footwall at Loma Prieta. Interestingly, the North American Plate is composed largely of faulted Mesozoic subduction-complex rocks in both locations, whereas the opposing Pacific Plate is composed of massive Mesozoic granitic rocks overlain by Cenozoic sediments.

Fuis and others (2017) speculate that the change in dip of the SAF at 6-km depth minimizes rupture energy, where rheology has changed upward from elastic (earthquake-producing) in the midcrust to nonlinear (poorly earthquake-producing) in the upper crust (see Hauksson, 2015). The concept is that it takes more work to move rock along a longer, moderately dipping fault than along a shorter, steeply dipping fault in the nonlinear upper crust. This hypothesis could be tested numerically. The approach of the fault to the free surface is also likely a factor for the change in dip and flower-like structure development (Ma, 2008, 2009; see discussion in Fuis and others, 2017).

In the Coachella Valley, as at Loma Prieta, geodetic deformation data also support a dipping SAF (see Fialko, 2006; Lindsey and Fialko, 2013; and Fattaruso and others, 2014), but these data do not resolve the nonplanar geometry of the SAF. 


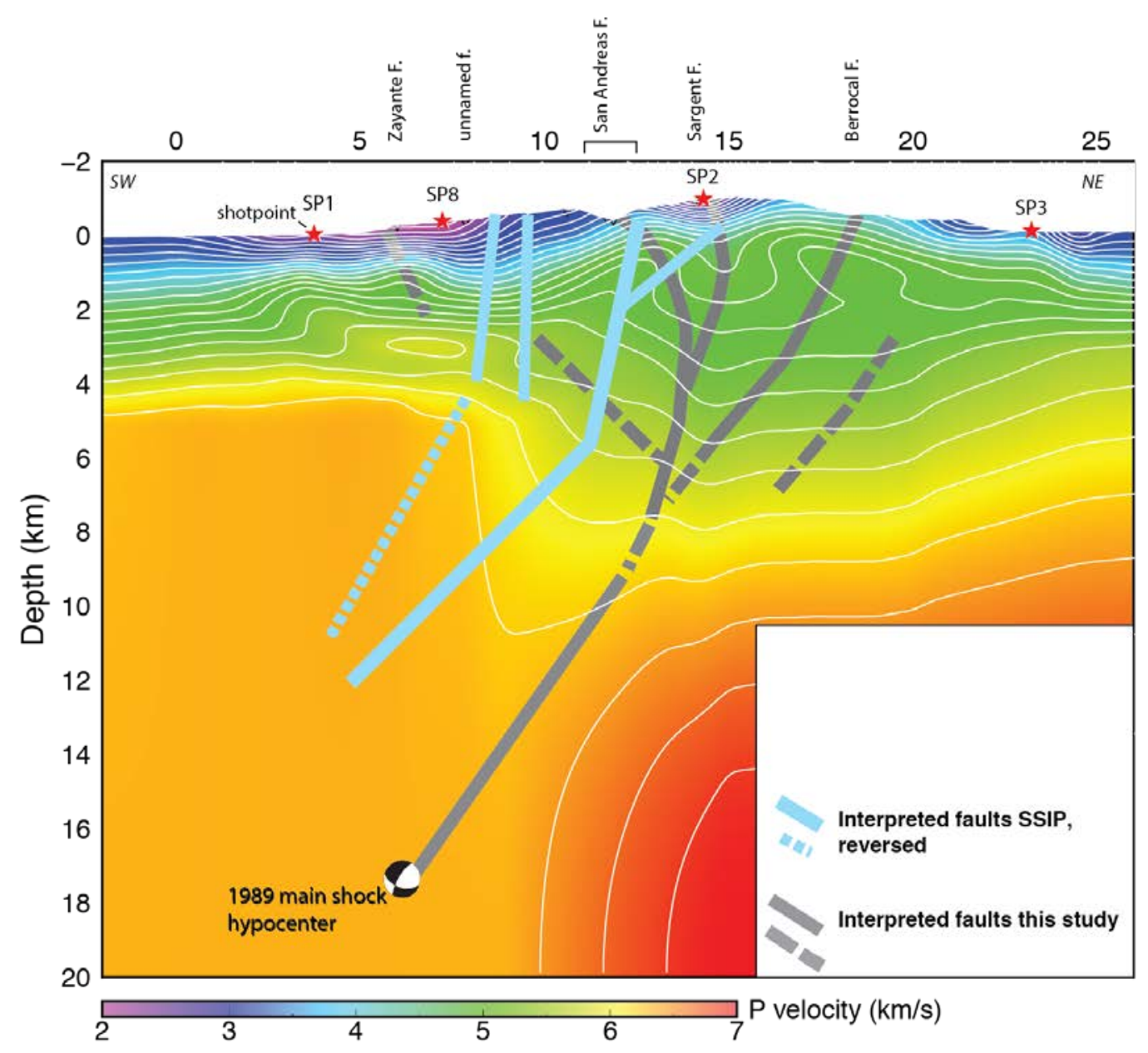

Figure 21. Comparison of fault structure geometry in the epicentral area of the 1989 Loma Prieta, California, earthquake interpreted from this study with that interpreted for line 4 of the Salton Seismic Imaging Project (SSIP). Note: SSIP fault dips are reversed to more easily compare with Loma Prieta fault geometry. Contour interval 0.2 kilometer per second (km/s) (see fig. 2B). km, kilometers; F., Fault; P, compressional wave; SW, southwest; NE, northeast.

\section{Conclusions}

Initial interpretations of fault structure in the vicinity of the 1989 Loma Prieta earthquake were constrained by routine network earthquake locations and geodetic data. A change in dip of the SAF at 6-10 km and a surrounding flower-like structure were permissible interpretations from these data, but the prevailing interpretation was that the mainshock rupture occurred on a secondary fault within the San Andreas Fault Zone. Aftershock relocations, steep reflections extracted from a 1991 seismic refraction profile, and examination of potential-field models on nearby profiles better resolve the subsurface geometry of faults in this region, supporting, instead, a change in dip of the SAF itself in the mid-crust.

Interpreted SAF geometry in the Coachella Valley is also constrained by steep reflections, hypocenters, and potential field data. Here the SAF shows a similar change in dip at about 6-km depth and an associated flower-like structure. However, in the Coachella Valley the flower-like structure mainly occurs in the hanging wall of the SAF, and in contrast at Loma Prieta, it mainly occurs in the 
footwall. Geodetic data permit a dipping SAF in both the Coachella Valley and in the vicinity of the 1989 Loma Prieta earthquake.

The similarities between the Loma Prieta fault geometry and the better constrained Coachella Valley fault geometry lend support to our hypothesis that the main Loma Prieta rupture occurred on the SAF itself, with a 2-part dip, rather than on a secondary fault, as previously proposed.

\section{Acknowledgments}

The authors gratefully acknowledge reviews of a draft of this manuscript by Tom Brocher and Pat McCrory (USGS). Our interpretations were also aided by discussion with USGS colleagues. Jim Hendley (USGS) kindly provided editing, formatting, and other helpful input.

\section{References Cited}

Bauer, K., Ryberg, T., Fuis, G.S., and Lueth, S., 2013, Seismic imaging of the Waltham Canyon fault, California: comparison of ray-theoretical and Fresnel volume prestack depth migration: Bulletin Seismological Society America, v. 103, p. 340-352, https://doi.org/10.1785/0120110338.

Beroza, G.C., 1996, Rupture history of the earthquake from high-frequency strong-motion data, in Spudich, P.A., ed., The Loma Prieta, California, earthquake of October 17, 1989—Main shock characteristics: U.S. Geological Survey Professional Paper 1550-A, p. 9-32, https://pubs.usgs.gov/pp/pp1550/pp1550a/.

Bleibinhaus, F., Hole, J.A., Ryberg, T., and Fuis, G.S., 2007, Structure of the California Coast Ranges and San Andreas Fault at SAFOD from seismic waveform inversion and reflection imaging: Journal of Geophysical Research, v. 112, B06315, https://doi.org/10.1029/2006JB004611.

Bürgmann, R., Segall, P., Lisowski, M., and Svarc, J.L., 1997, Post seismic strain following the Loma Prieta earthquake from repeated GPS measurements, in Reasenberg, P.A., ed., The Loma Prieta, California, earthquake of October 17, 1989-Aftershocks and postseismic effects: U.S. Geological Survey Professional Paper 1550-D, p. 209-252, https://pubs.usgs.gov/pp/pp1550/pp1550d/.

Catchings, R.D., Goldman, M.R., Steedman, C.E., and Gandhok, G., 2004, Velocity models, first-arrival travel times, and geometries of 1991 and 1993 USGS land-based controlled-source seismic investigations in the San Francisco Bay area, California-In-line shots: U.S. Geological Survey OpenFile Report 2004-1423, p. 32, https://pubs.usgs.gov/of/2004/1423/.

Clark, S.P., Jr., 1966, Handbook of physical constants: Geological Society of America Memoir, v. 97, 587 p., https://doi.org/10.1130/MEM97.

Dietz, L.D., and Ellsworth, W.L., 1990, The October 17, 1989, Loma Prieta, California, earthquake and its aftershocks: geometry of the sequence from high-resolution locations: Geophysical Research Letters, v. 17, no. 9, p. 1417-1420.

Dietz, L.D., and Ellsworth, W.L., 1997, Aftershocks of the Loma Prieta earthquake and their tectonic implications, in Reasenberg, P.A., ed., The Loma Prieta, California, earthquake of October 17, 1989-Aftershocks and postseismic effects: U.S. Geological Survey Professional Paper 1550-D, p. 5-47, https://pubs.usgs.gov/pp/pp1550/pp1550d/.

Eberhart-Phillips, D., and Michael, A.J., 1998, Seismotectonics of the Loma Prieta, California, region determined from three-dimensional Vp, Vp/Vs, and seismicity: Journal of Geophysical Research, v. 103, p. 21099-21120.

Eberhart-Phillips, D., and Michael, A.J., 2004, Seismotectonics of the Loma Prieta region determined from three-dimensional P-wave velocities, Vp/Vs ratios, and seismicity, in Wells, R.E., ed., The Loma Prieta, California, Earthquake of October 17, 1989-Geologic setting and crustal structure: 
U.S. Geological Survey Professional Paper 1550-E, p. 165-188, https://pubs.usgs.gov/pp/pp1550/pp1550e/.

Fattaruso, L.A., Cooke, M.L., and Dorsey, R.J., 2014, Sensitivity of uplift patterns to dip of the San Andreas fault in the Coachella Valley, California: Geosphere, v. 10, p. 1235-1246, https://doi.org/10.1130/GES01050.1.

Feld, C., Mechie, J., Hübscher, C., Hall, J., Nicolaides, S., Gurbuz, C., Bauer, K., Louden, K., and Weber, M., 2017, Crustal structure of the Eratosthenes Seamount, Cyprus and S. Turkey from an amphibian wide-angle seismic profile: Tectonophysics, v. 700-701, p. 32-59, https://doi.org/10.1016/j.tecto.2017.02.003.

Fialko, Y., 2006, Interseismic strain accumulation and the earthquake potential on the southern San Andreas fault system: Nature, v. 441, p. 968-971, https://doi.org/10.1038/nature04797.

Fuis, G.S., Bauer, K., Goldman, M.R., Ryberg, T., Langenheim, V.E., Scheirer, D.S., Rymer, M.J., Stock, J.M., Hole, J.A., Catchings, R.D., Graves, R.W., and Aagaard, B., 2017, Subsurface geometry of the San Andreas fault in southern California: results from the Salton Seismic Imaging Project (SSIP) and strong ground motion expectations: Bulletin Seismological Society America, v. 107, p. 1642-1662, https://doi.org/10.1785/0120160309.

Hauksson, E., 2015, Exploring the brittle-ductile transition at the base of the seismogenic zone of the crust in Southern California-Implications for crustal rheology [abs.]: American Geophysical Union 2015 Fall Meeting, San Francisco, Calif., 14-18 Dec., abstract T51H-04.

Hauksson, E., Yang, W., and Shearer, P. M., 2012, Waveform relocated earthquake catalog for southern California (1981-June 2011): Bulletin Seismological Society America, v. 104, p. 2239-2244.

Hole, J., 1992, Nonlinear high-resolution three-dimensional seismic travel time tomography: Journal Geophysical Research, v. 97, p. 6553-6562.

Jachens, R.C., and Griscom, A., 2004, Geophysical and geologic setting of the earthquake, inferred from gravity and magnetic anomalies, in Wells, R.A., ed., The Loma Prieta, California, earthquake of October 17, 1989-Geologic setting and crustal structure: U.S. Geological Survey Professional Paper 1550-E, p. 49-80, https://pubs.usgs.gov/pp/pp1550/pp1550e/.

Jennings, C.W., and Bryant, W.A., 2010, Fault activity map of California: California Geological Survey Geologic Data Map No. 6, map scale 1:750,000.

Lay, T., and Wallace, T.C., 1995, Modern global seismology, vol. 58: Academic Press, 521 p.

Lindsey, E.O., and Fialko, Y., 2013, Geodetic slip rates in the southern San Andreas Fault systemEffects of elastic heterogeneity and fault geometry: Journal Geophysical Research, v. 118, p. 689697, https://doi.org/10.1029/2012JB009358.

Ma, S., 2008, A physical model for widespread near-surface and fault zone damage induced by earthquakes: Geochemistry, Geophysics, Geosystems, v. 9, Q11009, https://doi.org/10.1029/2008GC002231.

Ma, S., 2009, Distinct asymmetry in rupture-induced inelastic strain across dipping faults-An off-fault yielding model: Geophysical Research Letters, v. 36, L20317, https://doi.org/10.1029/2009GL040666.

Marshall, G.A., and Stein, R.S., 1997, Elevation changes associated with the earthquake and their use to infer fault-slip geometry, in Spudich, P.A., ed., The Loma Prieta, California, earthquake of October 17, 1989—Main shock characteristics: U.S. Geological Survey Professional Paper 1550-A, p. 105146, https://pubs.usgs.gov/pp/pp1550/pp1550a/.

McLaughlin, R.J., and Clark, J.C., 2004, Stratigraphy and structure across the San Andreas fault zone in the Loma Prieta region and deformation during the earthquake, in Wells, R.E., ed., The Loma Prieta, 
California, earthquake of October 17, 1989-Geologic setting and crustal structure: U.S. Geological Survey Professional Paper 1550-E, p. 5-48, https://pubs.usgs.gov/pp/pp1550/pp1550e/.

Northern California Earthquake Data Center, 2014, Northern California Earthquake Data Center: University of California Berkeley Seismological Laboratory dataset, accessed March 4, 2018, at https://doi.org/10.7932/NCEDC.

Powell, R.E., 1993, Balanced palinspastic reconstruction of pre-late Cenozoic paleogeology, southern California-Geologic and kinematic constraints on evolution of the San Andreas fault system, in Powell, R.E., Weldon, R.J., II, and Matti, J.C., eds., The San Andreas fault system-Displacement, palinspastic reconstruction, and geologic evolution, Geologic Society America Memoir 178, p. 1-106.

Reasenberg, P.A., 1997, Introduction, in Reasenberg, P.A., ed., The Loma Prieta, California, earthquake of October 17, 1989-Aftershocks and postseismic effects: U.S. Geological Survey Professional Paper 1550-D, p. 1-4, https://pubs.usgs.gov/pp/pp1550/pp1550d/.

Ryberg, T., and Fuis, G.S., 1998, The San Gabriel Mountains bright reflective zone-Possible evidence of young mid-crustal thrust faulting in southern California: Tectonophysics, v. 286, p. 31-46.

Ryberg, T., Haberland, C., Haberlau, T., Weber, M.H., Bauer, K., Behrmann, J.H., and Jokat, W., 2015, Crustal structure of northwest Namibia-Evidence for plume-rift-continent interaction: Geology, v. 43, p. 739-742, https://doi.org/10.1130/G36768.1.

Schaff, D.P., and Waldhauser, F., 2005, Waveform cross-correlation-based differential travel-time measurements at the Northern California Seismic Network: Bulletin Seismological Society America, v. 95, p. 2446-2461.

Spudich, P.A., 1996, Synopsis, in Spudich, P.A., ed., The Loma Prieta, California, earthquake of October 17, 1989-Main shock characteristics: U.S. Geological Survey Professional Paper 1550-A, p. 1-8, https://pubs.usgs.gov/pp/pp1550/pp1550a/.

Waldhauser, F., and Schaff, D.P., 2008a, Double-difference earthquake catalog for northern California, 1984-2011 version 201112.1: Lamont-Doherty Earth Observatory, Columbia University, database, accessed March 4, 2018, at http://www.ldeo.columbia.edu/ felixw/NCAeqDD/.

Waldhauser, F., and Schaff, D.P., 2008b, Large-scale relocation of two decades of northern California seismicity using cross-correlation and double-difference methods: Journal of Geophysical Research, v. 113, B08311, https://doi.org/10.1029/2007JB005479.

Wells, R.E., 2004, Introduction, in Wells, R.E., ed., The Loma Prieta, California, earthquake of October 17, 1989-Geologic setting and crustal structure: U.S. Geological Survey Professional Paper 1550-E, p. 1-4, https://pubs.usgs.gov/pp/pp1550/pp1550e/.

Yang, W., Hauksson, E., and Shearer, P.M., 2012, Computing a large, refined catalog of focal mechanisms for southern California (1981-2010)—Temporal stability of the style of faulting: Bulletin Seismological Society America, v. 102, p. 1179-1194. 


\section{Appendix 1-Comparison of Results from Broad and Narrow Top Mutes}

When one compares reflections obtained in epicentral area of the 1989 Loma Prieta earthquake using a broad versus a narrow top mute, one sees similarities, but many more reflections are obtained using the narrow top mute (fig. 22). The broad top mute eliminates 3-4 peaks following first arrivals, whereas the narrow top mute eliminates only 2-3 peaks. These extra reflections from the narrow top mute are not necessarily all interpretable.

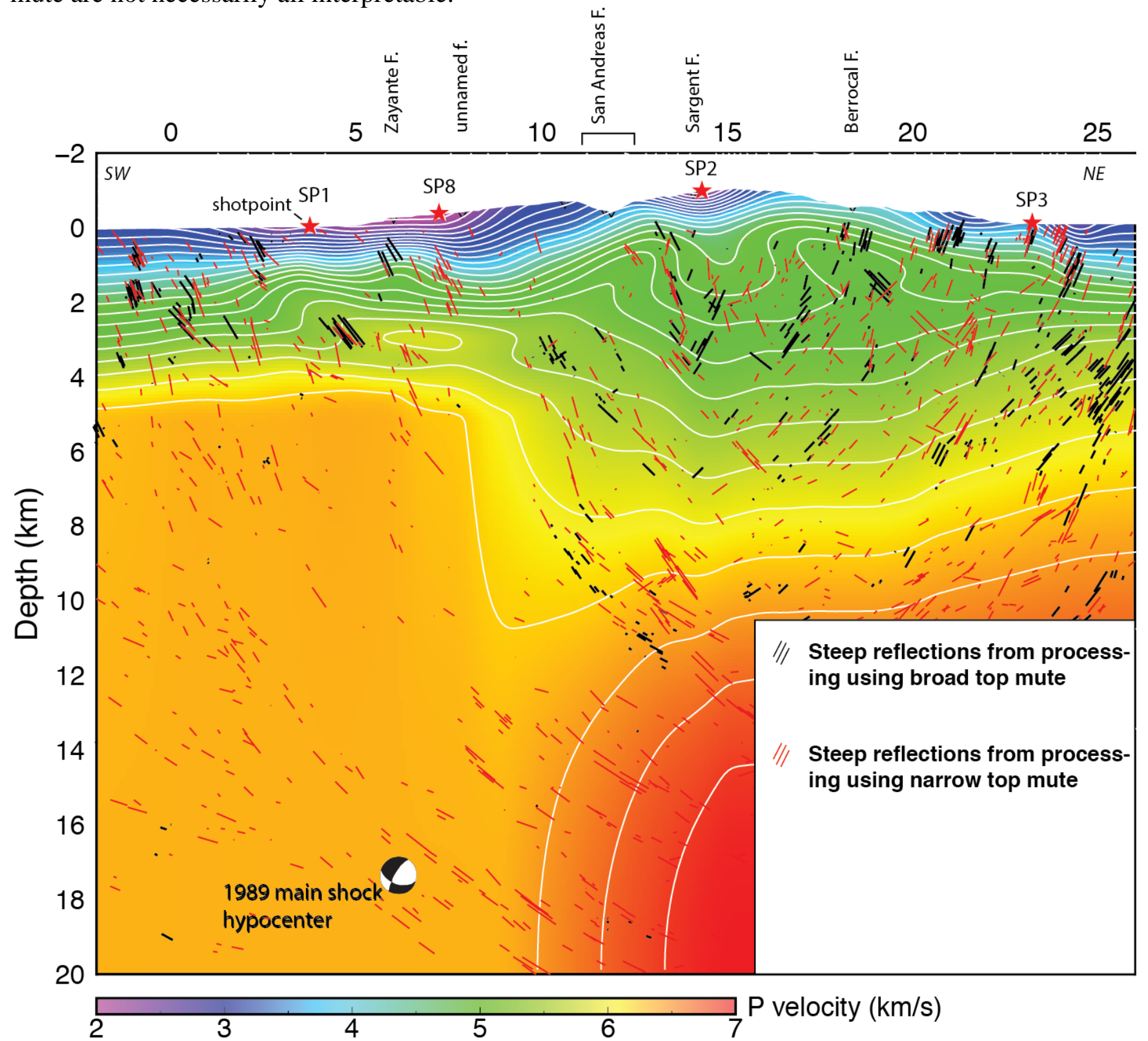

Figure 22. Comparison of reflections obtained in the epicentral area of the 1989 Loma Prieta, California, earthquake using a broad top mute (black; eliminating 3-4 peaks following the first arrivals) with reflections from using a narrow top mute (red; eliminating 2-3 peaks following first arrivals). F., Fault; km, kilometers; km/s, kilometers per second; P, compressional wave; SW, southwest; NE, northeast. 


\section{Appendix 2-Steep-Dip Reflection Analysis}

Our reflection analysis for the epicentral area of the 1989 Loma Prieta earthquake consisted of automatic detection of coherent secondary arrivals in individual record sections followed by prestack migration of these detected phases using the technique of Bauer and others (2013). Preprocessing of the seismic reflection data included dead trace removal, trace DC removal, bandpass filtering (10-20 Hz), spectral whitening, and automatic gain control. The work flow applied after the preprocessing is illustrated by a synthetic example in figure 23. Shot-gathered data are analyzed in the time domain using a moving window (fig. 23A). Only windowed samples are considered. A point $i$ is chosen at the center of this window in which a semblance analysis is carried out (fig. 23B). Local slant stacks over neighboring traces are calculated for a given range of slowness values. The local slant stack with the highest semblance (coherency) value defines the local slowness of the wave field at the analyzed sample i. Only samples with a slowness reverse to the first-arrival phase (reverse moveout) are considered in this study, because reflections from steep faults can be detected by such a moveout (for example, Bauer and others, 2013). A line segment is drawn in the time domain with the corresponding dip and centered at the analyzed sample (fig. 23B). A prestack migration is then used to map the line segment from the time domain into the depth domain based on a given velocity model (fig. 23C). A ray is shot from the receiver downward. The initial angle of the ray is defined by the given velocity at the receiver and the slowness $\left(p_{i}\right)$ derived from the semblance analysis. The line is migrated to the location where the ray crosses the isochrone. The isochrone represents subsurface locations of equal reflection time $t_{i}$ for a given coherent sample $i$. Finally, the line segment is drawn at the migration point with the local dip in the depth domain. More details on the prestack line migration are described in Bauer and others (2013). Applications of the method and more practical aspects can be found in Ryberg and others (2015) and Feld and others (2017). 

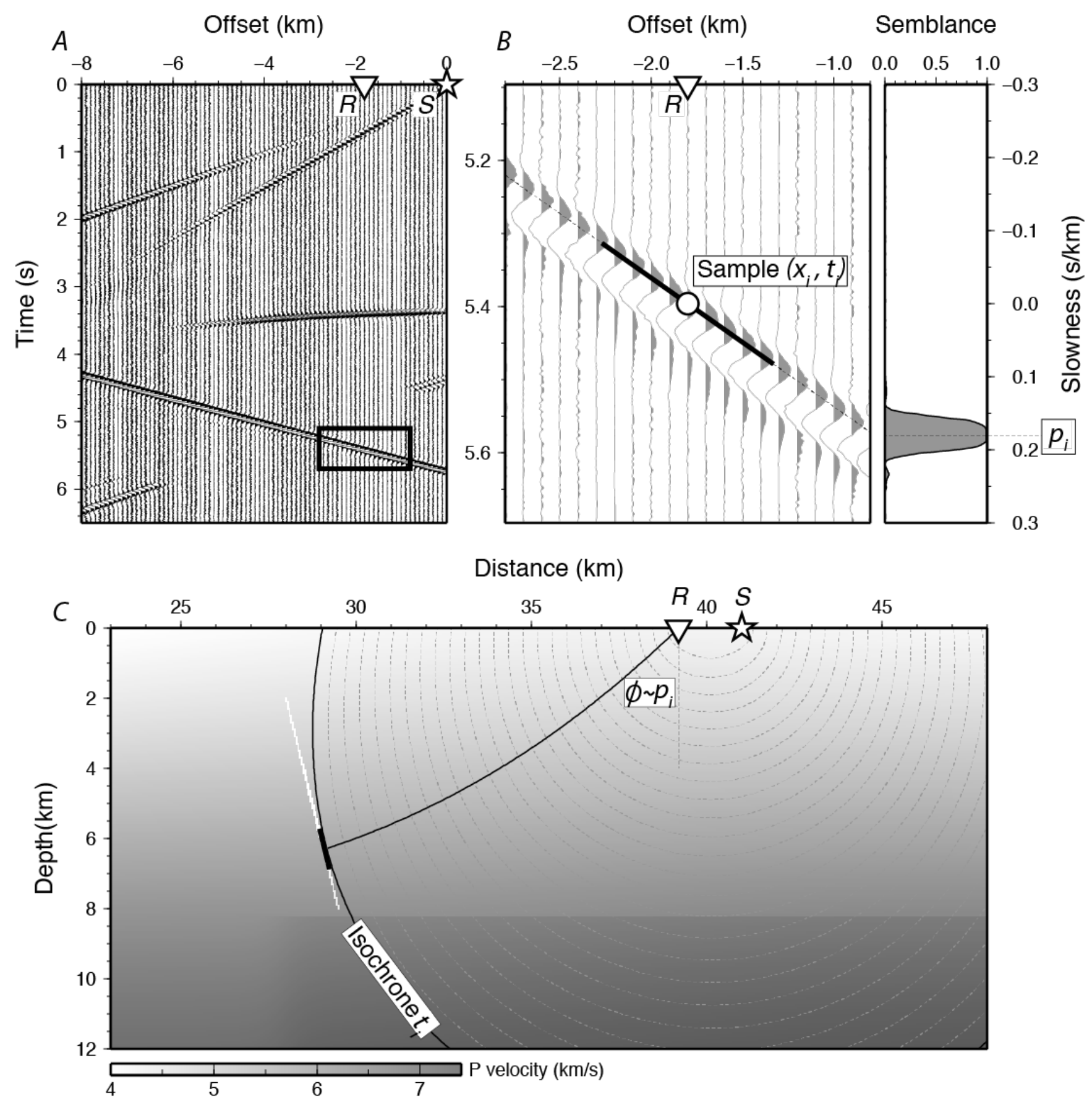

Figure 23. Diagrams showing the prestack migration technique of Bauer and others (2013). A, Synthetic data illustrating the prestack line-migration method. $R$, receiver; $S$, shotpoint. Black rectangle is moving window in which maximum semblance is calculated. $B$, Enlargement of moving window of $A$ in which semblance analysis is carried out. Small circle is the point of calculation centered at offset, $x_{i}$, and time, $t_{i}$, for $R$. The line segment (bold black line) corresponds to the slowness, $p_{i}$, with the maximum semblance (coherency) for this window. $C$, Prestack migration to map the line segment from time to depth domain. Ray tracing starts at $R$. The initial ray direction, $\Phi$, is a function of local $p_{i}$ derived by the semblance analysis. The migration point is determined where the ray crosses the isochrone for reflection time $t_{i}$. Note that the white line tangent to isochrone $t_{i}$ is the low-velocity fault zone causing the reflection. $\mathrm{km}$, kilometers; $\mathrm{km} / \mathrm{s}$, kilometers per second; $\mathrm{P}$, compressional wave. 
ISSN 2331-1258 (online)

https://doi.org/10.3133/ofr20181093 